OPEN ACCESS

Edited by:

Carla Pinheiro,

New University of Lisbon, Portugal

Reviewed by:

Ali Saadoun,

UDELAR, Uruguay

Jean-Francois Hocquette,

INRA UMR1213 Herbivores, France

*Correspondence:

Stephan van Vliet

stephan.vanvliet@duke.edu

Specialty section:

This article was submitted to Agroecology and Ecosystem Services,

a section of the journal

Frontiers in Sustainable Food Systems

Received: 23 April 2020

Accepted: 22 July 2020

Published: 06 October 2020

Citation:

van Vliet S, Kronberg SL and

Provenza FD (2020) Plant-Based Meats, Human Health, and Climate

Change.

Front. Sustain. Food Syst. 4:128.

doi: 10.3389/fsufs. 2020.00128

\section{Plant-Based Meats, Human Health, and Climate Change}

\author{
Stephan van Vliet ${ }^{1 *}$, Scott L. Kronberg ${ }^{2}$ and Frederick D. Provenza ${ }^{3}$ \\ ${ }^{1}$ Duke Molecular Physiology Institute, Duke University Medical Center, Durham, NC, United States, ${ }^{2}$ Northern Great Plains \\ Research Laboratory, USDA-Agricultural Research Service, Mandan, ND, United States, ${ }^{3}$ Department of Wildland \\ Resources, Utah State University, Logan, UT, United States
}

There is wide scale concern about the effects of red meat on human health and climate change. Plant-based meat alternatives, designed to mimic the sensory experience and nutritional value of red meat, have recently been introduced into consumer markets. Plant-based meats are marketed under the premise of environmental and human health benefits and are aimed appeal to a broad consumer base. Meat production is critiqued for its overuse of water supplies, landscape degradation, and greenhouse gas emission, and depending on production practices, environmental footprints may be lower with plant-based meat alternatives. Life-cycle analyses suggest that the novel plant-based meat alternatives have an environmental footprint that may be lower than beef finished in feedlots, but higher than beef raised on well-managed pastures. In this review, we discuss the nutritional and ecological impacts of eating plant-based meat alternatives vs. animal meats. Most humans fall on a spectrum of omnivory: they satisfy some nutrient requirements better from plant foods, while needs for other nutrients are met more readily from animal foods. Animal foods also facilitate the uptake of several plant-derived nutrients (zinc and iron), while plant nutrients can offer protection against potentially harmful compounds in cooked meat. Thus, plant and animal foods operate in symbiotic ways to improve human health. The mimicking of animal foods using isolated plant proteins, fats, vitamins, and minerals likely underestimates the true nutritional complexity of whole foods in their natural state, which contain hundreds to thousands of nutrients that impact human health. Novel plant-based meat alternatives should arguably be treated as meat alternatives in terms of sensory experience, but not as true meat replacements in terms of nutrition. If consumers wish to replace some of their meat with plant-based alternatives in the diet (a "flexitarian approach") this is unlikely to negatively impact their overall nutrient status, but this also depends on what other foods are in their diet and the life stage of the individual.

Keywords: plant-based meat, sustainability, meat, nutrition, diet, climate change, vegetarian and nonvegetarian diet

\section{INTRODUCTION}

Novel plant-based meat alternatives such as the Impossible ${ }^{\mathrm{TM}}$ Burger and Beyond Burger ${ }^{\circledR}$ are becoming increasingly popular with consumers and have attracted considerable financial investments, media coverage, and research attention. Their success has led other food companies to produce their own versions of these products. The plant-based meat market is growing rapidly 
and is expected to be worth more than $\$ 30$ billion by 2026 (Statista, 2020. ${ }^{1}$ ). Meat alternatives, formulated to mimic the taste and sensory experience of red meat, are marketed for their ecological and health benefits compared to red meat. While ingredients vary amongst plant-based meat products, the new generation of alternatives is formulated specifically to mimic the sensory experience and macronutrient content of meat by using plant proteins (e.g., soy, pea, potato, rice, wheat, and/or myocprotein), fats (e.g., canola, coconut, soybean, and/or sunflower oil), and other novel ingredients (e.g., soy leghemoglobin, red-colored vegetable extracts, and/or flavoring agents). Additionally, various vitamins and minerals that are naturally found in meat (e.g., zinc, iron, and Bvitamins) are increasingly added to plant-based meats (Curtain and Grafenauer, 2019). By doing so, novel plant-based meat alternatives are able to closely mimic the Nutrition Facts panels of meat (Figure 1). Plant-based meats may also reduce apprehensions regarding the effects of red meat on human health and climate change, and fit with recommendations for dietary transitions toward reduced meat consumption and increased plant-based diets, particularly in Western civilization (Godfray et al., 2018; Graça et al., 2019). Moreover, the novel meat alternatives are particularly targeted at flexitarians-omnivores who are looking to eat less animal foods. Given the close resemblance of novel plant-based meat alternatives to meat, we will discuss the nutritional and ecological impacts of eating plantbased meat alternatives vs. animal meats, while also providing a broader discussion of the ecological and health effects of replacing animal foods with plant foods.

\section{NUTRIENTS IN PLANT-BASED MEATS AND MEAT}

\section{Omnivory or Optionality?}

A core question in discussions of replacing animal foods with plant-based substitutes is whether plant-based substitutes can adequately satisfy nutrition requirements. As omnivores, humans tend to satisfy some nutrients more readily from plant sources while other nutrient requirements are generally better satisfied by consumption of animal foods. For example, our vitamin C and magnesium requirements are much more readily fulfilled by plant than animal foods. In addition, plant-based diets are often higher in folate, manganese, thiamin, potassium, and vitamin E (Davey et al., 2003). Plant foods also provide a wide array of phytochemicals that have important regulatory roles in human health (Briskin, 2000). The findings of extensive in vitro and in vivo experimental data, furthermore, suggest that plant compounds can antagonize some of the deleterious effects of compounds found in cooked red meat (e.g., heterocyclic amines, nitroso compounds, malondialdehyde, advanced glycation end products etc.) (Pierre et al., 2003; Vulcain et al., 2005; Gorelik et al., 2008; Hur et al., 2009; Li et al., 2010; Van Hecke et al., 2017a).

These findings may represent a mechanistic explanation-but certainly not the only one-for why high quality omnivorous

${ }^{1}$ Statista (2020). https://www.statista.com/. diets (also rich in plants) do not show the typical associations between red meat consumption and negative health outcomes (Key et al., 2003; Schulze et al., 2003; Kappeler et al., 2013; Lee et al., 2013; Roussell et al., 2014; Wright et al., 2018; Deoula et al., 2019) that are often observed in population studies of individuals consuming a typical Standard American/Western Diet (Wang and Beydoun, 2009; Chan et al., 2011; Pan et al., 2011; Micha et al., 2012; Abete et al., 2014), though more work is needed to firmly establish this hypothesis.

On the other hand, vitamins $\mathrm{A}$ (retinol), $\mathrm{B}_{12}$ (adenosyl- and hydroxocobalamin), D (cholecalciferol), $\mathrm{K}_{2}$ (menaquinone-4), minerals such as iron and zinc, and long-chain polyunsaturated fatty acid (PUFAs) (e.g., docosahexaenoic acid [DHA] and eicosapentaenoic acid [EPA]) are more readily, or exclusively, obtained from animal sources as opposed to plant sources. These nutrients play essential roles in tissue development and regeneration (Georgieff, 2007; van Vliet et al., 2018). While plant foods often contain precursors to these nutrients, considerable portions of the population experience a poor in vivo enzymatic conversion of plant-precursors into forms usable by the human body (Brenna, 2002; Burdge, 2006; Tang, 2010). For example, the conversion of carotenoids (provitamin A) to retinol (vitamin A) is in the range of $\sim 3.5$ to $28 \%$, depending on the genetic variability between individuals, and highlights that "poor converters" are unable to obtain sufficient retinol when relying on plant foods only. Retinol deficiency is especially prevalent in the developing world, particularly in young children and women of childbearing age, who largely depend on the consumption of provitamin A (primarily $\beta$-carotene) in vegetables and fruit to satisfy their vitamin A needs, with many failing to do so (Sommer and Vyas, 2012).

Of course, individual genetic differences related to nutrient metabolism (Brenna, 2002; Burdge, 2006; Stover and Caudill, 2008; Tang, 2010), at the same time, also explain why some individuals can thrive on plant-based diets, while others following a vegan/vegetarian diet report health problems associated with nutrient deficiencies. For example, there are five times more former vegans/vegetarians than current vegans/vegetarians in the US, of which 53\% reported that they followed the diet $<12$ months (Faunalytics, 2015). While many factors contribute to the difficulties in adhering to plant-based diets (including social factors and food options), intra-individual differences in nutrient metabolism (Brenna, 2002; Burdge, 2006; Stover and Caudill, 2008; Tang, 2010; van Vliet et al., 2015) make it highly unlikely that everyone can thrive on a plant-based diet. The same is likely true for those on "carnivorous" diets (mostly or exclusively animal foods) (Mcclellan and Du Bois, 1930), though more work is needed to confirm this hypothesis.

While human omnivory should arguably not be interpreted as true optionality for either plant or animal foods, concerns regarding the negative effects of animal foods on human and environmental health have led to widespread suggestions to replace traditional animal foods with plant-based foods to meet the vast majority of our nutritional needs (Godfray et al., 2018; Willett et al., 2019). The shift toward replacing animal foods with plant substitutes is, furthermore, enabled by modern food technologies that allow for the production of plant-sourced 


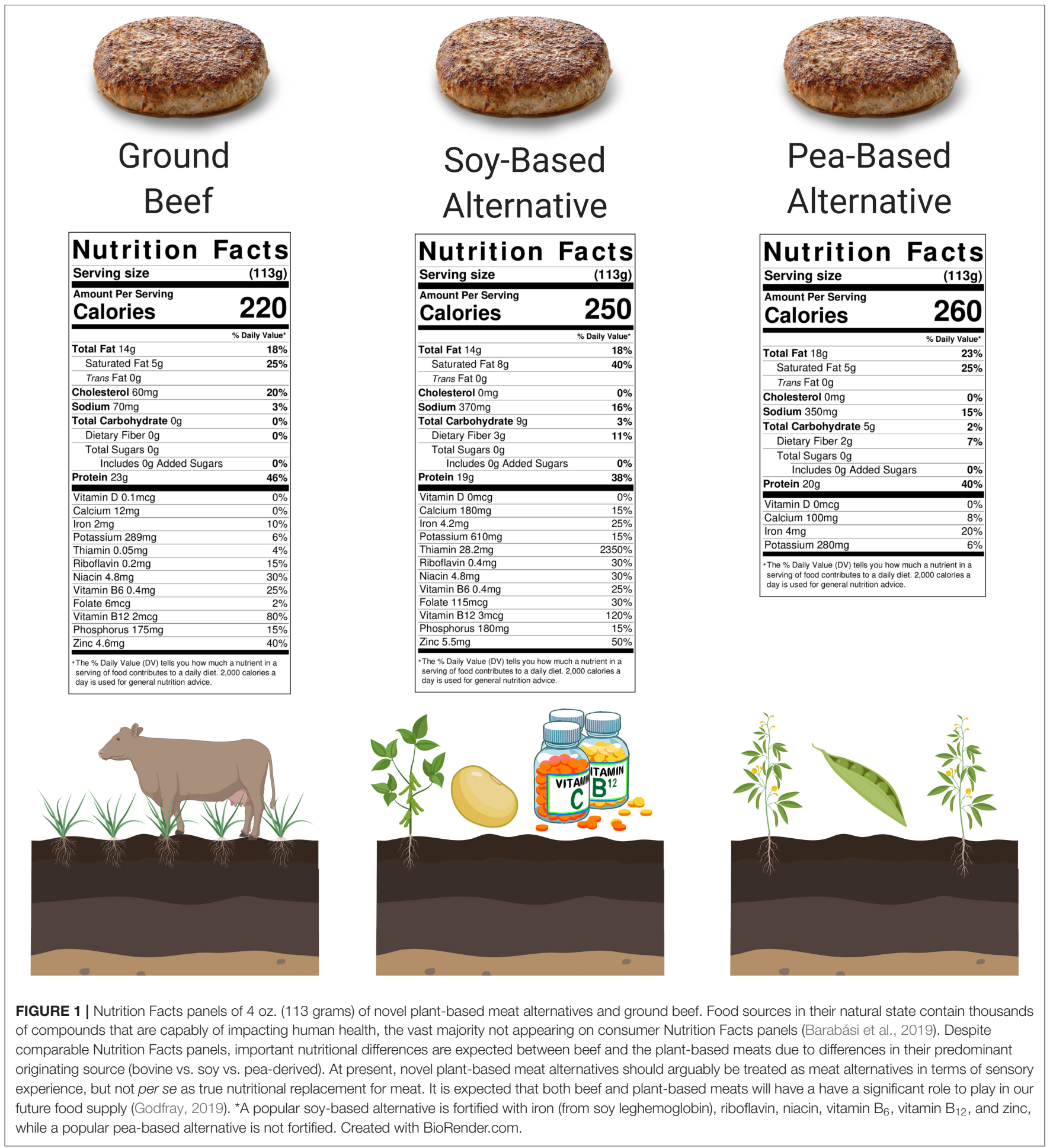

foods that are able to match the macronutrient, vitamin and mineral content of animal foods by using isolated plant proteins, bioengineered ingredients, and/or synthetic vitamins and minerals (Figure 1).

Moreover, a potential reason why the novel plant-based meats that look, feel, and taste like meat are of interest to consumers is that they may be able to better satisfy the "intrinsic desire" that humans have for eating meat (Piazza et al., 2015). For example, despite an aversion in vegetarians toward animal foods at the subjective level, the intrinsic motivational salience (desire for meat) was preserved on the neural level similar to that of omnivores (Giraldo et al., 2019). Noteworthy, is that 
this "subconscious motivation for eating meat" was observed already after a single overnight fast, which is far from a starvation-like state. Given the close resemblance of novel plantbased meat alternatives to meat, in the following section we address the following question: Can plant-based alternatives meet the nutritional requirements traditionally fulfilled by eating animal foods?

\section{Protein}

The recommended dietary allowance (RDA) for protein in adults is $0.8 \mathrm{~g}$ protein $/ \mathrm{kg}$ bodyweight per day $(\sim 56 \mathrm{~g}$ for a $70 \mathrm{~kg}$ individual) (Institute of Medicine, 2005). However, this amount should be viewed as the minimum to prevent deficiency in young adulthood rather that an amount that promotes optimal health (Wolfe and Miller, 2008; Phillips et al., 2016). Furthermore, the protein RDA is considered too low for middle-aged and older adults (>50 y) (Bauer et al., 2013; Deutz et al., 2014), and for adults who seek to maximize cellular adaptations from regular physical activity/exercise (Kato et al., 2016; Morton et al., 2018).

Animal foods such as meat are often recommended to meet protein needs because they provide dietary protein at a modest caloric load, and are considered of higher protein quality when compared to plant sources (FAO/WHO/UNI, 2011). The protein digestibility-corrected amino acid score (PDCAAS) and digestible indispensable amino acid score (DIAAS) are the two major standards used to evaluate the quality of dietary protein sources. Plant proteins often have lower scores (ranging from 0.4 to 0.9 ) than animal proteins ( $>0.9$ ). The lower PDCAAS/DIAAS of plant sources is, in part, due to their reduced digestibility as a result of the presence of "anti-nutrients"-phytates and trypsin inhibitors that interfere with digestion and absorption of protein (Sarwar Gilani et al., 2012). The advantage of novel meat alternatives is that they use concentrates and/or isolates of soy, pea, and other plant proteins. These purified protein sources are lower in anti-nutritional factors and, therefore, have comparable PDCAAS/DIAAS to most animal proteins including meat (Rutherfurd et al., 2014; Hodgkinson et al., 2018).

Based on their respective PDCAAS/DIAAS, one could expect that isolated plant proteins would result in a similar anabolic response when compared to animal sources. However, a number of studies have demonstrated that purified plant proteins have a lower skeletal muscle anabolic response when compared to isonitrogenous amounts of animal proteins with similar PDCAAS/DIAAS (Wilkinson et al., 2007; Tang et al., 2009; Phillips, 2012; Yang et al., 2012; Gorissen et al., 2016). Plant proteins tend to be particularly low in either lysine or methionine as well as leucine, which are essential amino acids that cannot be synthesized in vivo and need to be obtained through the diet (van Vliet et al., 2015). For instance, both soy and pea protein, the most commonly used protein sources in novel plant-based alternatives, are particularly low in methionine when compared to beef, in addition to being slightly lower in lysine as well (Figure 2).

The issue of an unbalanced amino acid profile can be solved by combining isolated plant proteins that are lower in lysine yet higher in methionine (e.g., wheat, rice, hemp, and maize) with plant proteins that are higher in lysine yet lower in methionine (e.g., soy, potato, and pea) in a single product or

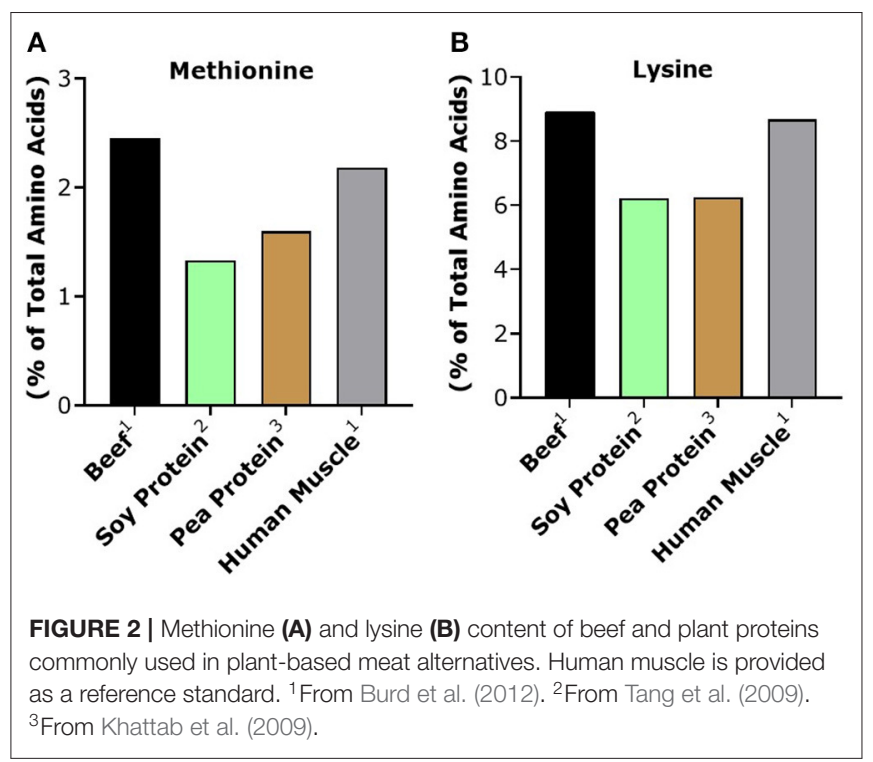

by adding crystalline amino acids to the product (van Vliet et al., 2015). While a popular pea-based alternative contains some isolated rice protein, which is complementary to pea protein, it is unlikely (based on the listed order of ingredients) that the amount is sufficient to increase the methionine content of the product. Similarly, a popular soy-based alternative has a limited amount of potato protein ( $<2 \%$ of total ingredients), but potato, like soy, is low in methionine and high in lysine. While we have previously theorized that blending different complementary plant sources is a promising strategy to improve the skeletal muscle anabolic response to ingested plant protein (van Vliet et al., 2015), no studies have yet determined if this brings the muscle anabolic response from plant sources up to the level of animal proteins. Of note is recent work that showed that consumption of complementary plant proteins still resulted in $30-40 \%$ lower circulating essential amino acid availability when compared to a leucine-matched amount of whey protein (Brennan et al., 2019). These data suggest that, despite the blending of plant-based sources to make a complete amino acid profile, the anabolic potential may still be reduced when compared to animal-based protein.

A potential alternative strategy to overcome the lower anabolic effects of plant vs. animal proteins is to simply eat more plant proteins. Consuming $40 \mathrm{~g}$ of soy protein results in a similar muscle anabolic response as $20 \mathrm{~g}$ of whey protein (Yang et al., 2012). Adding a high dose of rice protein ( $48 \mathrm{~g}$ ) to an omnivorous diet is also as effective as a protein-matched amount of whey protein in augmenting resistance-exercise induced gains in muscle mass. This is in contrast to studies that show a superior training-induced skeletal muscle gains after consuming lower doses of animal vs. plant proteins (ranging from 17.5 to $25 \mathrm{~g}$ ) (Hartman et al., 2007; Volek et al., 2013). Nonetheless, it may reasonably be expected that the consumption of plant-based meat alternatives as part of an omnivorous diet is unlikely to negatively impact skeletal muscle mass or affect protein requirements. 


\section{Vitamin $\mathrm{B}_{\mathbf{1 2}}$}

The cobalamins (vitamin B12) are the best-known members of the group of compounds collectively known as corrinoids. Cobalamin (vitamin $\mathrm{B}_{12}$ ) is an essential nutrient that plays a role in DNA synthesis, myelin formation, red blood cell production, and maintenance of central nervous system function (Yamada, 2013). Humans must obtain vitamin $B_{12}$ from the foods they eat or via supplementation. While gut bacteria in our large intestine still produce some corrinoids, including small amounts of active forms of cobalamin (Kirmiz et al., 2020), evolutionary pressures likely resulted in preferential absorption of $\mathrm{B}_{12}$ in the small intestine as a result of regular animal consumption (Seetharam and Alpers, 1982). This has resulted in a dependence on exogenous $B_{12}$ that has likely persisted for at least $1.5 \mathrm{Ma}$ (Dominguez-Rodrigo et al., 2012). Indeed, the receptors necessary for absorbing $\mathrm{B}_{12}$ are found only in the small intestine in modern-day humans, upstream of the site of bacterial corrinoid production (Seetharam and Alpers, 1982).

Biologically active $B_{12}$ is found predominantly as adenosyl cobalamin in animal flesh (Czerwonka et al., 2014) and as hydroxocobalamin in eggs and dairy (Matte et al., 2012). These active forms of vitamin $\mathrm{B}_{12}$ bioaccumulate in animal products predominantly through microbial synthesis in the gut of ruminants, through consumption of soil and feces in nonruminant herbivores, and through phytoplankton consumption in aquatic animals (Watanabe and Bito, 2018). A common misperception is that the majority of cattle receive supplemental $\mathrm{B}_{12}$ and that humans are essentially consuming $\mathrm{B}_{12}$ supplements via a "middle-man." While there is some evidence that highproducing dairy cows need more $\mathrm{B}_{12}$ than their microbes produce (Girard and Matte, 2005; Akins et al., 2013), the reality is that $B_{12}$ is seldom fed to cattle, which is likely due to its high cost and limited benefits for production (Akins et al., 2013).

Although limited amounts of $\mathrm{B}_{12}$ are also found in some plant foods, such as mushrooms and fermented vegetables, the majority of $\mathrm{B}_{12}$ in plants are biologically inactive corrinoids (i.e., $B_{12}$ analogs) (Stupperich and Nexø, 1991) that may compete with transport of biologically active B12, thus potentially aggravating a $B_{12}$ deficiency (Dagnelie et al., 1991). Several plant-based foods, particularly those meant to replace animal foods-cereals, nondairy milks, vegan spreads, and plant-based meat replacementsare often fortified with supplemental $B_{12}$ to counteract deficiency. The common supplemental form of $\mathrm{B}_{12}$ used in these products is cyanocobalamin which is relatively inexpensive to produce and has stability to heat exposure (Goldstein and Duca, 1982).

Cyanocobalamin is a man-made form of Vitamin $B_{12}$ that normally occurs only in trace amounts in human tissue, particularly in smokers (Paul and Brady, 2017). While all forms of vitamin $\mathrm{B}_{12}$-naturally occurring adenosylcobalamin and hydroxycobalamin and the man-made form cyanocobalaminare absorbed with similar efficiency (Paul and Brady, 2017), a potential concern with meeting $B_{12}$ requirements through cyanocobalamin is that its tissue retention rates, and subsequent metabolic activity, are reduced compared to naturally occurring forms of $\mathrm{B}_{12}$ (Glass et al., 1961; Hertz et al., 1964; Okuda et al., 1973; Paul and Brady, 2017). Additionally, the $B_{12}$ found in animal foods is protein-bound and therefore partially protected from light degradation (Linnell and Matthews, 1984). Nonetheless, eating cyanocobalamin-fortified foods or ingesting cyanocobalamin supplements can improve vitamin $B_{12}$ status in adults (Tucker et al., 2000, 2004; Damayanti et al., 2018) and children (Sheng et al., 2019), which is also why fortifying meat alternatives with $B_{12}$ is encouraged. This is especially important for vegans and vegetarians, and the elderly (even omnivores) who often have low $\mathrm{B}_{12}$ status (Herrmann et al., 2003a,b; Andrès et al., 2004), and rely on food fortification and/or supplementation to meet $B_{12}$ needs. It is important to highlight that only less than a quarter of plant-based meat substitutes are fortified with $B_{12}$ (Curtain and Grafenauer, 2019).

\section{Iron}

Dietary iron is found as heme iron in animal foods, particularly in red meat, and as non-heme iron in plant foods, particularly in pulses, grains, green leafy vegetables, and certain fruits. Heme iron is 5-10-fold more bioavailable than non-heme iron (Hurrell and Egli, 2010), and explains why omnivores often have higher serum ferritin levels (a marker of iron status) (Haider et al., 2018). The uptake of iron, particularly non-heme iron, is limited by several plant compounds such as phytates, polyphenols, and calcium, present in both plants and dairy (Hurrell and Egli, 2010).

In contrast to most plant foods, which predominantly contain non-heme iron as part of their natural food matrix, the iron in a market leading soy-based alternative is heme iron purified from yeast that is genetically engineered to express the leghemoglobin protein normally found in the root nodules of soy plants (i.e., soy leghemoglobin) (Fraser et al., 2018). While the amino acid sequence of leghemoglobin is vastly different from animal heme counterparts, iron uptake of leghemoglobin had similar bioavailability as bovine hemoglobin in a human epithelial cell culture model (Proulx and Reddy, 2006). Importantly, initial studies regarding safety of yeast-derived soy leghemoglobin show little concern for genotoxicity and immunogenicity in in vitro and short-term (28-day) in vivo animal studies (Fraser et al., 2018; Jin et al., 2018). Future work should confirm the bioavailability and long-term safety of yeast-derived soy leghemoglobin consumption in vivo in humans, and particularly in children where soy allergy is more common (Savage et al., 2010). While some concern exists with consumers regarding the use of genetically modified ingredients in food products (Scott et al., 2018), a recent consumer survey suggests that the presence of soy leghemoglobin in a popular soy-based meat alternative does not appear to be a barrier to consumption or perceived healthfulness of the product (International Food Information Council, 2020).

A market leading pea-based meat alternative contains nonheme iron naturally present in peas (Figure 1). While the bioavailability of non-heme iron is reduced compared to heme, non-heme iron can still represent an important dietary source of iron (Young et al., 2018). Vitamin C, and ironically meat, are main enhancers of non-heme iron absorption (Hurrell and Egli, 2010), which is why adding meat to plant-based meals improves uptake of non-heme iron from plants (BjornRasmussen and Hallberg, 1979; Kristensen et al., 2005). Vitamin $\mathrm{C}$ also enhances iron uptake by acting as a chelator in the gut 
(Conrad and Umbreit, 1993). Important to note is that a market leading soy-based meat alternative is supplemented with sodium ascorbate (vitamin C), which presumably counteracts some of the inhibitory effects of the phytates, found in soy protein, on iron absorption (Hurrell et al., 1992).

Despite increased awareness, iron deficiency remains one of the most common nutrient deficiencies in both developed and developing countries, and population groups such as children, adolescent females, and older individuals are particularly at risk for deficiency (Patel, 2008; Beck et al., 2014; Gibson et al., 2014). On the other hand, excessive heme iron intake is increasingly linked to the promotion of cardiovascular disease (CVD) (Fang et al., 2015). The association of heme iron intake and CVD is particularly prevalent in US cohorts, but is inconsistent in cohorts outside of the US (Fang et al., 2015). Interestingly, even in the US the association between high heme iron intake and risk of CVD was absent in the first cohort of NHANES, which was studied during the 1970s (Liao et al., 1994) when red meat intake was higher compared to present day (Daniel et al., 2011). This heterogeneity between studies likely suggests that the background diet in which red meat is consumed may be an important modulating factor. In particular, the deleterious effects of red meat consumption may be perpetuated when meat is consumed as part of the Standard American Diet, rich in processed foods and inadequately counterbalanced with whole food plant sources. For example, polyphenols, phytates, calcium, and fibers inhibit heme iron absorption (Hurrell and Egli, 2010; Ma et al., 2010), and this may explain why some epidemiolocal studies find that risk of heme iron intake and CVD disappears with extensive adjustment for diet quality (i.e., diets also high in whole plant foods) (Galan et al., 2009; de Oliveira Otto et al., 2012; Kaluza et al., 2014).

\section{Zinc}

Similar to iron, zinc deficiency can be a concern in both developed and developing countries (Alloway, 2008), and those who restrict animal foods often have lower zinc status (Foster et al., 2013; Foster and Samman, 2015). Uptake of zinc from plant sources can be lower as a result of the presence of antinutrients such as phytates, lectins, and certain fibers (Harland and Oberleas, 1987; Welch, 1993). Similar to iron, zinc uptake from plants can be improved when consumed in conjunction with animal foods (Sandström et al., 1989). While soy protein contains limited amounts of zinc, a popular soy-based alternative is fortified with zinc gluconate to bring its level up to that of beef (Figure 1). Nevertheless, zinc absorption from fortified plant foods, at equal zinc content of beef, is lower than that for beef (Zheng et al., 1993; Etcheverry et al., 2006). We note that a wellplanned vegan diet rich in legumes, nuts, seeds, and other zincrich plant foods can potentially provide adequate amounts of zinc (Eshel et al., 2019). Of further consideration when meeting zinc (and iron) requirements with supplementation is that this practice may reduce the absorption of other minerals such as copper (Yadrick et al., 1989), thus increasing their dietary requirements. The latter can be mitigated by consuming copperrich (plant) foods (e.g., nuts, seeds, and leafy greens).

\section{Essential Fatty Acids}

The $\omega-6$ fatty acid linoleic acid (C18:2, LNA) and the $\omega$ 3 fatty acid alpha-linolenic acid (C18:3, ALA) are essential fatty acids that cannot be synthesized in vivo by humans and must be obtained from dietary sources (Barcelo-Coblijn and Murphy, 2009). ALA is the parent precursor to the longchain polyunsaturated fatty acids (LCPUFA) eicosapentaenoic acid (C20:5 n-3, EPA) and docosahexaenoic acid (C22:6 n-3, DHA). ALA and LNA are commonly found in plant foods but can also be found in limited quantities in animal foods, while DHA and EPA are found exclusively in animal foods and certain algae.

While ALA can be converted to DHA and EPA through a series of elongation and desaturation steps, this conversion is poor and often $<1 \%$ (Su et al., 1999; Brenna, 2002; Pawlosky et al., 2003). Moreover, this conversion efficiency also depends on the presence of co-factors such as selenium, zinc, iron and vitamin $\mathrm{B}_{6}$ (Brenner, 1981), which are less bioavailable from plant foods. For these reasons, vegetarians can have lower levels of DHA and EPA when compared to omnivores (Rosell et al., 2005).

DHA and EPA have been studied extensively for their importance in cardiovascular function, immunomodulation, vision, and cognitive function (Swanson et al., 2012). DHA is a major constituent of the brain phospholipid membrane (30$40 \%$ of total fatty acids), and low circulating levels are associated with accelerated brain aging (Tan et al., 2012; Otsuka et al., 2014). Nonetheless, as studies suggest that the human brain only requires $5 \mathrm{mg}$ of DHA per day (Rapoport et al., 2007; Umhau et al., 2009), it is estimated that $1,200 \mathrm{mg}$ of ALA can provide these minimum requirements (Barcelo-Coblijn and Murphy, 2009), though this minimum amount is not considered optimal for health. While no official daily recommended intakes exist for DHA and EPA, numerous studies demonstrate that combined intakes of DHA and EPA ranging from 250 to $1000 \mathrm{mg} /$ day improve cognitive function and other health parameters (YurkoMauro et al., 2015; Derbyshire, 2018), and such amounts are therefore often recommended by various health organizations (WHO, 2008; EFSA, 2012).

The $\omega-3$ fatty acid ALA is found in substantial amounts in certain vegetable oils, such as flax seed oil (53\% ALA), chia seed oil (64\% ALA), perilla oil (60\% ALA), and camelina oil $(38 \%$ ALA), though consumption of the latter two oils is generally restricted to Asian and Nordic countries, respectively (BarceloCoblijn and Murphy, 2009). While the amount of ALA necessary to ensure minimum DHA requirements in the human body can be obtained with modest intake of these oils, the majority of vegetable oils consumed in industrialized countries is in the form of $\omega$-6 LNA-rich seed oils such as soybean, corn, sunflower, and canola oil, which contain $<10 \%$ ALA. For instance, sunflower oil and canola oil-the main oils in the novel plant-based meat alternatives-contain only $1 \%$ (sunflower oil) and 10\% (canola oil) ALA. Given the already low conversion rates of ALA to EPA and DHA, respectively, plant-based meat alternatives in their current state likely will not provide meaningful amounts of very long-chain PUFAs in the diet. 
Another potential issue is that the $\omega-6$ fatty acids such as LNA directly compete with ALA for enzymes involved in elongation and desaturation, which further diminishes the ability to obtain DHA and EPA from ALA (Sprecher et al., 1999). This is particularly problematic when one considers that the increased consumption of high LNA seed oils in the modern Western Diet has resulted in an $\omega$-6-to- $\omega$-3 fatty acid ratio of 16:1 (Simopoulos, 2002), whereas historical intakes puts this ratio closer to 1:1 (Eaton et al., 1998; Simopoulos, 2002). This high $\omega-$ 6-to- $\omega-3$ fatty acid ratio is considered an important underlying cause for the increasing incidence of metabolic disease and all-cause mortality in Western countries (Das, 2006; Zhuang et al., 2019). Experimentally substituting $\omega$-6-rich LNA oils with $\omega$-3-rich ALA oils reduces inflammation (Rallidis et al., 2003; Bemelmans et al., 2004), which represent a mechanistic explanation for why consuming $\omega$-3-rich ALA oils may be cardioprotective. Thus, a suitable improvement to the novel plant-based meat alternatives could be to consider the use of high ALA oils, rich in $\omega-3$, instead of high LNA oils rich in w-6 fatty acids. An important consideration is that high ALA oils are more prone to lipid oxidation (and perhaps represents a reason why high LNA oils are typically used in meat substitutes); however, the addition of natural anti-oxidants (Wang et al., 2018; Lu et al., 2020) as well as entrapment of high ALA oils with isolated plant proteins (Karaca et al., 2013; Bajaj et al., 2015) represent worthwhile opportunities to explore for producers of plant-based meat substitutes that consider the use of high ALA oils in their products, which potentially increases their healthfulness.

It is often stated that $\omega-3$ fatty acids are present in such modest amounts in land animal-sourced foods, such as beef, that they do not represent a valuable dietary source of these essential fatty acids. However, this notion fails to take into account the abundance of the $\omega-3$ fatty acid docosapentaenoic acid (C22:5, DPA) in beef, particularly pasture-raised beef, which raises platelet EPA and DHA levels as a result of in vivo conversion (McAfee et al., 2011). While DHA can also be directly obtained in substantial amounts from offal cuts of meat-for instance, $100 \mathrm{~g}$ of grass-fed beef liver provides $80 \mathrm{mg}$ of DHA (Enser et al., 1998) - the consumption of organ meat is not as common anymore in Western diets and marine sources account for the majority of dietary intake of the $\omega-3$ fatty acids DHA and EPA (Bauch et al., 2006; Papanikolaou et al., 2014).

\section{Secondary Nutrients}

While we have highlighted several important individual nutrients thus far, foods in their natural state are considerably more complex than their essential fatty acid, amino acid, vitamin, and mineral content would suggest. Food sources contain hundredsto-thousands of biochemicals that are important to human metabolism (Barabási et al., 2019). While many of these nutrients are considered non-essential or conditionally-essential based on life-stages, and are often less appreciated in discussions of human nutritional requirements, their ability to impact human metabolism should not be ignored.

For example, creatine has been studied extensively for its ability to enhance athletic performance (Cooper et al., 2012), but creatine also plays an important role in cognition (Avgerinos et al., 2018). As creatine is found only in animal foods, vegans and vegetarians often have lower bodily stores (Burke et al., 2003), and vegetarians provided with supplemental creatine showed substantial improvements in memory tasks (Benton and Donohoe, 2011). Similarly, the antioxidants anserine, carnosine, and taurine are found (almost) exclusively in animal foods (Hou et al., 2019). Increased anserine and carnosine intake provide neurocognitive protection in humans (Szczesniak et al., 2014; Rokicki et al., 2015).

Taurine is an amino acid found almost exclusively in animal foods and though small amounts may be found in some plant foods such as cereals, legumes, and grains (a thousand times less when compared to animals foods) (Pasantes et al., 1989), these amounts are insufficient to meet human requirements (Laidlaw et al., 1990). It is often stated that since taurine can be synthesized in vivo from methionine and cysteine via cysteinesulfinic acid decarboxylase (CSD), taurine requirements can be met by consumption of plant proteins that are rich in methionine and cysteine, which can be found in adequate amounts in several legumes and grains (van Vliet et al., 2015). However, CSD levels in the human body, which allows for the conversion of taurine from methionine and cysteine, are insufficient to maintain tissue concentrations over time (Ripps and Shen, 2012). Taurine impacts nearly every vital organ in the body and plays vital roles in eye health (Froger et al., 2014), brain function (Kilb and Fukuda, 2017), mitochondrial functions (Suzuki et al., 2002), skeletal muscle cell differentiation (Miyazaki et al., 2013), and cardiovascular health (Waldron et al., 2018). Future studies are needed to better understand how these differences in secondary nutrients between plant-based meat alternatives and meat impacts short- and long-term health.

\section{Fortifying Foods to Mimic the Natural Food Source}

A recurring concern is that natural whole foods are extremely complex and the reductionist approach of trying to "mimic" whole food sources (whether it be meat or other foods) by combining several isolated nutrients likely underestimates the true complexity and health benefits of eating whole foods (Lichtenstein and Russell, 2005; Jacobs and Tapsell, 2007). In particular, fortification of a low-meat diet with zinc and other minerals found in meat did not result in similar zinc status as when these minerals were provided in the diet as part of the natural matrix of meat (Hunt et al., 1995). Moreover, adequate intakes of zinc, copper, and vitamins $\mathrm{A}$ and $\mathrm{D}$ were associated with decreased risk of cardiovascular disease and all-cause mortality when obtained from foods, but not from supplements, in a recent large population-based study (Chen et al., 2019). Similarly, carotenoid-containing foods are associated with a decreased risk of various cancers (van Poppel and Goldbohm, 1995), retinopathies (Goldberg et al., 1988; Seddon et al., 1994), and cardiovascular disease (Kritchevsky, 1999). However, the results of interventional and epidemiological studies suggest that carotenoid and/or vitamin A supplements do not decrease the risk of cancer or cardiovascular disease, and might even 
raise the risk for some sub-populations (The Alpha-Tocopherol Beta Carotene Cancer Prevention Study Group, 1994; Omenn et al., 1996; Druesne-Pecollo et al., 2010; Bjelakovic et al., 2012). Similar findings have been made in studies of calcium that show a potential for increased cardiovascular disease risk with supplementation (Bolland et al., 2011; Li et al., 2012), but not when calcium is obtained from food (Xiao et al., 2013). Finally, similar findings have been made for vitamin $C$ and selenium supplements that show no benefits on mortality in a systematic review of RCTs comprised of nearly 300,000 individuals (Bjelakovic et al., 2012). Thus, it appears that simply ingesting these nutrients outside of their natural food matrices may not be an optimal solution for promoting health. Thus, obtaining nutrients from whole food sources as opposed to supplemental forms is emphasized regardless of the individual's diet (Jacobs and Tapsell, 2007; van Vliet et al., 2018).

\section{THE ECOLOGICAL IMPACTS OF PLANT-BASED MEAT VS. MEAT CONSUMPTION}

The plant vs. meat controversy takes on other dimensions when assessing environmental degradation and climate change, both of which adversely affect human health and are crucial considerations when making recommendations on diets for livestock and humans. Meeting requirements of nutrients with plant foods (e.g., folate, manganese, thiamin, copper, and $\beta$-carotene) may come at a lower environmental footprint (i.e., less greenhouse gas emissions) than when these nutrients are met with animal foods (Eshel et al., 2019). Nonetheless, it has been suggested that similar amounts of protein, iron, and vitamin A can be obtained from carefully selected plant-based diet at a lower carbon footprint when compared to omnivorous diets/animal foods (González et al., 2011; Eshel et al., 2019); however, such comparisons do not take into account the reduced bioaccessibility and bioavailability of plant sources for these nutrients (Stover and Caudill, 2008; Tang, 2010; van Vliet et al., 2015). Moreover, when footprints-land use for production and as greenhouse gas emissions (GHGE) - are calculated to consider amino acid content and nutrient density (e.g., iron, vitamin $B_{12}$, zinc, retinol, and amino acids), the footprint of animal foods may be more similar to plant foods (Drewnowski et al., 2015; Tessari et al., 2016) because animal foods can more readily meet our needs for these specific nutrients.

The lower carbon footprint of plant-based meat alternatives is touted as a main reason for choosing plant alternatives over beef. Recent life-cycle analysis (LCA) of the Beyond Burger ${ }^{\circledR}$ and the Impossible ${ }^{\mathrm{TM}}$ Burger demonstrates a smaller carbon footprint (+3.2 and $3.5 \mathrm{~kg} \mathrm{CO} 2$-eq emissions/per $\mathrm{kg}$ product, respectively) compared to US beef finished on total-mixed rations in feedlots (Heller and Keoleian, 2018; Quantis International, 2019a), which ranges from +10.2 to $+48.5 \mathrm{~kg} \mathrm{CO}$-eq per $\mathrm{kg}$ product, depending on the model used, the geographical location where the cattle are raised, and the inclusion of GHGE potential of retail, distribution, restaurant or at home use, and end-of-life

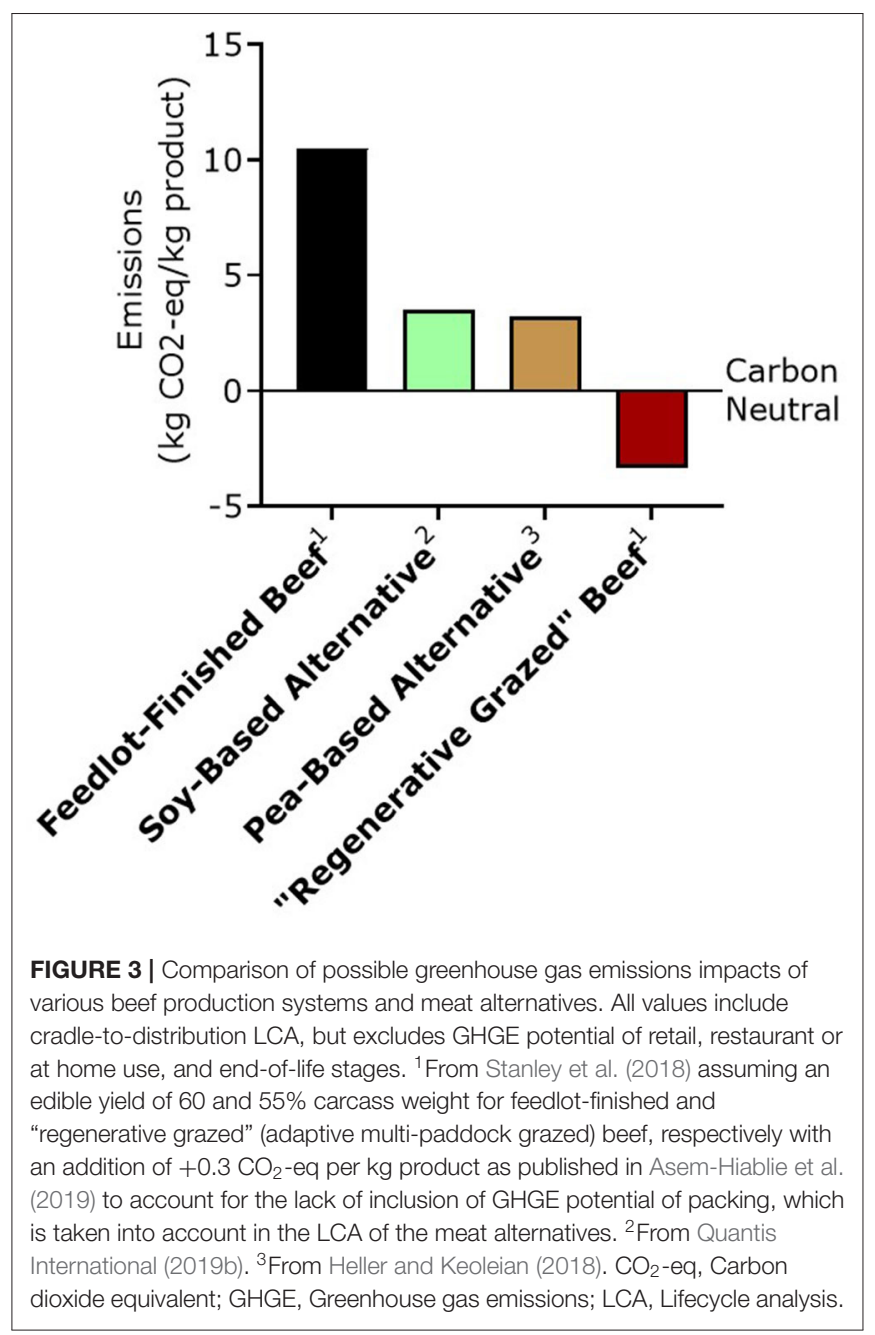

stages (Heller and Keoleian, 2018; Stanley et al., 2018; AsemHiablie et al., 2019; Rotz et al., 2019) (Figure 3).

While meat alternatives may have a lower environmental impact when compared to feedlot-finished beef, well-managed pasture-based livestock systems fix at a minimum all the GHG they emit (and sometimes more) even when taking into account all aspects of the production process (Allard et al., 2007; Teague et al., 2016; Stanley et al., 2018). Pastured beef systems that use land management practices such as rotational grazing-where lands are allowed to properly recover after a grazing periodand/or cover crop grazing suggest that the amounts of carbon sequestered in the soil more than offsets the ruminants' GHGE, resulting in a net negative carbon footprint (Allard et al., 2007; Teague et al., 2016; Stanley et al., 2018). By having livestock participate in carbon cycling by spending their lives on wellmanaged pastures-grooming and fertilizing vegetation and soil (Reeder and Schuman, 2002) — such production systems have the potential to help mitigate climate change (or in the very least not exacerbate it further) while ensuring a degree of food security (Teague et al., 2016).

Well-managed grasslands, especially in more mesic areas, can act as carbon sinks in a variety of geographical locations 
worldwide and depending on geographical locations, may be more reliable carbon sinks than forest (Dass et al., 2018; Viglizzo et al., 2019). It must be noted that the two (forests and livestock) are not mutually exclusive to begin with, as demonstrated by successful implementation of silvopastoralism-a type of agroforestry integrating trees, forage, and livestock-in forested areas across the globe as a strategy to enhance carbon sequestration, soil health, and food security for those inhabiting such areas (Kumar and Nair, 2011). Thus, considerations regarding livestock-production systems should be tailored to fit the geophysical landscape instead of attempting-often at great expense-to change the environment to fit the production system. For example, it would be suitable to practice silvopasture techniques with locally adapted animals in landscapes such as the Amazon rather than attempting to convert its forests to pasturelands (Nair et al., 2011).

It must be noted though that not all pasture-based (grass-fed) operations are per se regenerative or neutral, and depending on management practices, grass-fed beef systems can have a higher carbon footprint than some feedlot systems (Pierrehumbert and Eshel, 2015; Lynch, 2019). It is also important to highlight that the amount of carbon sequestered with well-managed grazing of livestock on carbon-depleted soils is initially more rapid and diminishes over time as soil health is restored (Godde et al., 2020), which is not surprising once equilibrium of ecological systems are reached. This notion should be considered in the discussions below.

By performing an ISO-compliant partial LCA of pastureraised (grass-fed) beef in the Midwest US, Stanley et al. (2018) found a net negative carbon footprint of $\sim-3.5 \mathrm{CO} 2$-eq/per $\mathrm{kg}$ beef (assuming a 55\% edible yield of hot carcass weight). We note that the value from the pasture-finished beef LCA assessment excludes the GHGE of getting the product case-ready, which is included in the plant-based meat LCAs. This is expected to add $+0.3 \mathrm{~kg}$ CO2-eq $/ \mathrm{kg}$ product (Asem-Hiablie et al., 2019) which would put the LCA analysis from so-called regenerative, grassfed beef at $-3.2 \mathrm{CO} 2-\mathrm{eq} /$ per $\mathrm{kg}$ beef (Figure 3). This means that over the lifecycle of the animal more carbon was sequestered than emitted.

Notably, the same company (Quantis International) that demonstrated a +3.5 CO2-eq emissions/per $\mathrm{kg}$ product in the LCA analysis of the Impossible Burger ${ }^{\mathrm{TM}}$ (Quantis International, 2019b) also demonstrated a -3.5 CO2-eq/per $\mathrm{kg}$ beef produced using regenerative livestock grazing practices (Quantis International, 2019a). While these reports are not peerreviewed, it is encouraging that the values reported by Quantis International are close to those reported in peer reviewed work on so-called regenerative beef (Stanley et al., 2018) and the work performed on plant-based meat alternatives by academic scientists (Heller and Keoleian, 2018).

Nonetheless, the LCAs performed on meat alternatives and pasture-finished beef both exclude GHGE potentials of retail, and restaurant or at home preparation, end-of-life stages, and other localized or indirect impacts. Acknowledging the difficulty in assessing all aspect of environmental footprints, future work should confirm these LCA analysis with full accounting for all
GHGE to provide for even-handed assessments (Halpern et al., 2019).

Greenhouse gasses are often lumped together under the umbrella of $\mathrm{CO}_{2}$-eq, which equates different GHGs to carbon dioxide $\left(\mathrm{CO}_{2}\right)$ (Allen et al., 2018). However, different gasses have different global warming potentials (GWP) and their exact values depend on the $\mathrm{CO}_{2}$-eq metrics and the timescale (e.g., 20 or 100 years) that is used to express its GHGE contribution (Lynch, 2019). While livestock production also includes significant emissions of $\mathrm{CH}_{4}$ (methane), plant based-meat emissions mostly consist of $\mathrm{CO}_{2}$ from energy generation (Heller and Keoleian, 2018). Livestock add $14.5 \%$ to GHGE globally (Gerber et al., 2013). Of that, $9.5 \%$ is producing feed for livestock, processing, and transportation, while the remaining $5 \%$ is methane from rumen (enteric) fermentation and manure. While methane is a potent GHG, it is also temporary one; it lasts a decade before it breaks down into $\mathrm{CO}_{2}$ that can be sequestered in soil. With a stable or slightly decreasing population of cattle in the US, though not globally, the methane belched from cattle is not likely to add new carbon to the atmosphere (Lynch, 2019). On the other hand, once we put carbon dioxide in the atmosphere from burning fossil fuel-whether from transportation or food production-it persists for thousands of years. These nuances are important to recognize in discussions on carbon footprints of different foods and dietary patterns.

The carbon footprint of meat alternatives is likely lower than the majority of beef consumed in the US, because that beef is produced primarily from feedlots that rely on fossil fuel-intensive methods (Poore and Nemecek, 2018) ( 96\% of all beef in the US is finished in feedlots). Some suggest that with increased conversion to pasture-based beef production systems in the US, domestic beef consumption will have to be reduced by about $40 \%$ due to unavailability of land-provided roughage feed is used to supplement cattle on pasture (Hayek and Garrett, 2018). These estimations do not take into account the potential for increased carrying capacity from multi-species grazing with little dietary overlap, for instance mixing cattle with sheep or goats, which improves productivity of both animals and vegetation when compared to grazing of either animal alone (Walker, 1994; Celaya et al., 2008; Anderson et al., 2012; Ferreira et al., 2013). Moreover, properly management multi-species grazing can also maintain plant diversity and thus improve ecological resiliency and pasture health (Anderson et al., 2012). This would obviously mean that we would have to diversify our meat and milk intake to include products from other livestock, including sheep, goats and perhaps smaller mammals such as ducks and rabbits.

Another opportunity to further increase the carrying capacity of a pasture-based livestock, which is often not taken into account in discussions on the carrying capacity of pasture-based production systems, is to strategically supplement livestock on pasture with edible by-products (Sunvold et al., 1991; Macdonald et al., 2007). Ruminants have the unique capacity to upcycle by-products from industrial and agricultural production (Mottet et al., 2017). For example, when corn is used to make ethanol, only the starch portion is used and its by-product (the outer shell, oil, and germ) can be made into a high-fat, high-protein cake fed 
to cattle. Crop residues such as straws, stover, and sugar-cane tops as well as phytochemically-rich byproducts of fruit and vegetable processing such as leaves, pomace, peels, rinds, pulp, seeds, stems etc. to livestock (Sruamsiri, 2007; Wadhwa and Bakshi, 2013; Nwafor et al., 2017) provide similar opportunities to upcycle these nutrients. Offering these byproducts to cattle on pasture can potentially mitigate some nutritional deficits, enhance use of unpalatable vegetation, reduce the risk of overgrazing, and mitigate issues of reduced land availability (Provenza et al., 2003).

Offering by-products on pasture, as opposed to feeding them to cattle in feedlots, would also mitigate some of the animal welfare issues associated with feedlots such as unfamiliar environments, inability to self-select their diet, and the ability to express natural behavior (Atwood et al., 2001; Villalba and Manteca, 2019). Offering by-products to cattle on pasture may represent a worthwhile opportunity for the livestock industry to improve consumer perception while maintaining the ability to upcycle by-products to meet customer demand. It will be important to use only industrial by-products that would have been produced anyway, rather than growing feed with the specific intent of giving it to livestock.

Recent studies also show that the mixture of forages animals eat on pasture influences how long it takes them to reach slaughter weight. Compared with grazing a monoculture of grass, cattle eating diverse mixtures of plants, some of which contain tannins, gain weight more efficiently and can reach finish body condition nearly as quickly as animals in feedlots-and they do so with less GHGE (Villalba et al., 2019). Providing ruminants with forages that contain secondary compounds such as tannins and terpenes also decreases nitrogen in urine and increases nitrogen in tannin-rich manure that builds soil organic matter (Villalba et al., 2019).

Finally, discussions on whether pasture-based productions systems can sustain meat consumption revolve around the ability of pasture-based systems to support the consumption of popular retail cuts (i.e., steaks, roasts, beef). For instance, Hayek and Garrett (2018) assume a 60\% edible yield in their calculations on the carrying capacity of pasture-based beef production systems to support US consumption. While this number is justifiable, another $20 \%$ of the animal is entirely suitable for human consumption and includes organs, bones, and tallow (USDA, 2015). For example, increased consumption of organ meatsoften much denser in vitamins and minerals (e.g., 10-1000 fold higher in retinol, iron, copper and vitamins $\mathrm{B}_{6}, \mathrm{~B}_{12}$, and $\mathrm{K}_{2}$ ) than muscle meat (USDA, 2016) - was recently found to reduce meat intake-associated GHGE by 14\% (Xue et al., 2019).

While not a panacea for saving the planet from climate change, agricultural practices that integrate regenerative livestock grazing practices with plant farming are an important step in the right direction to reduce the carbon footprint and land use of animal agriculture. Of 80 ways to mitigate climate change evaluated in Project Drawdown, regenerative practicesfarmland restoration, conservation agriculture, agroforestry, silvopastoralism, and managed grazing-jointly rank number one as a way to sequester GHG (Hawken, 2017). Furthermore, by integrating livestock grazing with plant farming, one can also improve crop yield and soil fertility (Maughan et al., 2009;
Bell et al., 2014). The symbiotic relationship between plants and herbivores, which each system strengthening the other, are important to appreciate in discussions on whether we displace livestock production.

When the projected increase to nearly ten billion people is combined with an increase of 32 percent in per-person-emissions from global shifts to ultra-processed diets by 2050, the net effect is an estimated 80 percent increase in GHGE (Tilman and Clark, 2014). Alternatively, GHGE may not increase if diets were vegetarian, pescatarian, or Mediterranean that include whole food sources of fruit, vegetables, seafood, grains, eggs, dairy, as well as limited amounts of beef, lamb, and poultry (Tilman and Clark, 2014). For example, the high carbon footprints in an urban Japanese population was largely explained by confectionary consumption, dining out, and alcohol consumption, whereas consumption of meat and vegetables contributed much less to the footprint-meat only contributed to $9 \%$ of the difference between low and high dietary carbon footprints (Kanemoto et al., 2019). Findings along similar lines were made recently in an Australian cohort, where "discretionary foods" (sugar-sweetened beverages, alcohol, confectionary, and other ultra-processed foods) made up the largest share of the environmental footprint (Ridoutt et al., 2020). Future studies should confirm this hypothesis in European and American households, but similar results can reasonably be expected due the prevalent consumption of the Standard Western/American diet.

Moreover, biophysical simulation of various diet patterns suggests that a healthy omnivorous diet-rich in whole-food plant and animal sources-has the greatest carrying capacity for feeding populations in diverse regions throughout the world (Peters et al., 2016). Vegan and vegetarian diets have a greater carrying capacity than the Standard Western Diet-high in processed foods (Peters et al., 2016). On this basis, some make a case for adoption of a plant-based diet, but a diet that contains only plant foods does not integrate farming and grazing to improve the fertility of soil-which synergistically strengthens both plant (Maughan et al., 2009; Bell et al., 2014) and livestock farming systems (Teague et al., 2016) - nor does it efficiently use land that could otherwise feed more people (Peters et al., 2016; Van Zanten et al., 2016). The latter point is significant because two-thirds of earth's land mass, which is unsuitable for crop production (FAO, 2020), is home to billions of people who depend on managed livestock grazing for their livelihood. In discussions of dietary transitions towards plant-based substitutes it is, therefore, crucial that no policies are set into place that threaten the health and livelihood of the world's poorest.

Another important point to consider is that most crops are grown in monocultures where life below and aboveground is sacrificed by chemical and/or mechanical means. While eating roots of carrots, seeds from almonds, or plant-based meat alternatives from peas or soy does not directly involve killing animals, indirectly it does. The habitats of other plants and animals are destroyed. One large and visible example is grassland birds who have lost more than $50 \%$ of their populations in North America in the last 50 years due to large-scale farming practices be it plant or animal farming (Rosenberg et al., 2019). Another clear example is found in the Southern Peninsula of 
Malaysia and Borneo where replacing native forests with oil palm plantations has contributed to a reduction in the total number bird and butterfly species by $~ 80 \%$ (Koh and Wilcove, 2008) and Orangutans by $85 \%$ (Ancrenaz et al., 2016).

There is considerable difficulty in estimating the number of animals killed as part of "collateral damage" in agriculture (i.e., animals not killed for consumption) (Fischer and Lamey, 2018); however, conservative yearly estimates in the US put this number in the tens of millions and includes mammals, fish, reptiles, and other amphibious creatures. In particular, Fischer and Lamey (2018) put this number at roughly 127.5 million field deaths per year in the US with a lower bound of 63.75 million per year, though it must be noted that considerable uncertainty exists regarding this number due to absence of systematic data collection on field deaths. For perspective, 40 million cattle and 120 million pigs are estimated to be slaughtered for consumption each year in the US (Fischer and Lamey, 2018). Whether intended deaths (through animal consumption) are morally equivalent to "unintended" deaths (through plant agriculture including those for human consumption and animal feed) is beyond this review [see Fischer and Lamey (2018) for a further discussion]. It serves the point that in food systems, life consumes life to live. Nonetheless, that improvements must be made in plant farming and livestock production methods in ways that enhance the welfare of livestock and wildlife is something arguably most agree on (meat and plant-eaters alike).

The ecological impacts of human diets are not as simple as plant vs. meat discussions might suggest. The global food system is far too diverse and contingent on unique environmental and socioeconomic circumstances to allow for one-size-fits-all policy recommendations. As the latest IPCC Report points out, mixed plant farming-livestock grazing systems can heal damage done by years of continuous arable cropping reliant on mechanical and chemical inputs (IPCC, 2019). In the process, we may increase the number of animals grazing phytochemically rich landscapes that nuture animals, soil, plants, and people, and provide food that is biochemically richer and arguably more nourishing for Homo sapiens and the planet.

\section{CONCLUSION}

Humans satisfy requirements for certain nutrients much better from plant foods, while needs for other nutrients are met more readily from animal foods. Plant nutrients (i.e., phytochemicals) often protect against potentially harmful compounds in cooked animal foods (Van Hecke et al., 2017b), while animal foods also facilitate the uptake of several plant nutrients (e.g., zinc and nonheme iron) (Sandström et al., 1989; Hurrell and Egli, 2010). Thus, plant and animal foods interact in symbiotic ways to improve human health.

While plant-based diets are being promoted for human and environmental health reasons (Eshel et al., 2019; Willett et al., 2019), this may put large portions of the population at greater risk for nutrient deficiencies and accompanying health issues (Payne et al., 2016). This may especially be the case for vulnerable populations such as children, elderly, and nursing mothers who are at increased risk for nutritional deficiencies. Some suggest that in order to meet requirements for several key nutrients with plant foods (vitamins $A, B_{3,6,12}$, choline, zinc, iron, and selenium), more plants should be ingested to overcome their reduced bioavailability and supplements should be taken if deficiencies arise (vitamin $B_{12}$ would have to be supplemented regardless). However, intra-individual differences in nutrient metabolism (Brenna, 2002; Burdge, 2006; Stover and Caudill, 2008; Tang, 2010) may preclude portions of the population to thrive on vegan/vegetarian diets, regardless of how well the plant-based food or diet may be "designed."

Many scientists are concerned about the reductionist approach of simply adding isolated forms protein, vitamins, and minerals to foods, or diets in general, and designating them as nutritionally adequate (Lichtenstein and Russell, 2005; Jacobs and Tapsell, 2007). As whole foods contain hundredsto-thousands of compounds that act synergistically to impact human health (Barabási et al., 2019), adding synthetic nutrients to food sources often does not confer similar benefits compared to when these nutrients are ingested as phytochemically and biochemically-rich whole foods-whether it be plant or animal foods (Lichtenstein and Russell, 2005; Jacobs and Tapsell, 2007).

Scientists who operate in the realms of nutrition and ecology, those in companies that produce plant-based meat alternatives, and the general public arguably share similar concerns about the influence of agriculture on climate change. Where groups differ is in their solution to the challenge. There are many whole-foods dietary options that could substantially improve human and ecological health (Tilman and Clark, 2014) - whether they be vegetarian, pescatarian, or omnivorous. We contend that an omnivorous diet rich in whole foods, produced using sustainable agricultural practices that integrates plants and animals in agroecological ways (i.e., in harmony with natural systems), is most likely to benefit human and ecological health.

At present, novel plant-based meat alternatives should arguably be treated as meat alternatives in terms of sensory experience, but not per se as true nutritional replacement for meat. If consumers wish to replace some meat in their diet with plant-based alternatives (a "flexitarian approach"), this is unlikely to negatively impact their overall nutrient status; however, this also depends on what other foods are routinely consumed and the life stage of the individual (e.g., infancy, pregnancy, or advancing age). That said, it is important for future work to compare human health outcomes in response plant-based vs. animal meat consumption. Such studies can ensure, and potentially improve, the healthfulness of plant-based meat alternatives and meat itself, as it is likely that both will have a have a significant role to play in our future food supply.

\section{AUTHOR CONTRIBUTIONS}

SV and FP wrote the first draft of the manuscript. SK critically revised the text and made substantial contributions to the manuscript. All authors approved the final version of the manuscript. 


\section{REFERENCES}

Abete, I., Romaguera, D., Vieira, A. R., Lopez De Munain, A., and Norat, T. (2014). Association between total, processed, red and white meat consumption and allcause, CVD and IHD mortality: a meta-analysis of cohort studies. Br. J. Nutr. 112, 762-775 doi: 10.1017/S000711451400124X

Akins, M. S., Bertics, S. J., Socha, M. T., and Shaver, R. D. (2013). Effects of cobalt supplementation and vitamin B12 injections on lactation performance and metabolism of Holstein dairy cows. J. Dairy Sci. 96, 1755-1768 doi: $10.3168 /$ jds.2012-5979

Allard, V., Soussana, J. F., Falcimagne, R., Berbigier, P., Bonnefond, J. M., Ceschia, E., et al. (2007). The role of grazing management for the net biome productivity and greenhouse gas budget $(\mathrm{CO} 2, \mathrm{~N} 2 \mathrm{O}$ and $\mathrm{CH} 4)$ of semi-natural grassland. Agric. Ecosyst. Environ. 121, 47-58. doi: 10.1016/j.agee.2006.12.004

Allen, M. R., Shine, K. P., Fuglestvedt, J. S., Millar, R. J., Cain, M., Frame, D. J., et al. (2018). A solution to the misrepresentations of $\mathrm{CO} 2$-equivalent emissions of short-lived climate pollutants under ambitious mitigation. Npj Climate Atmos. Sci. 1:16. doi: 10.1038/s41612-018-0026-8

Alloway, B. J. (2008). Zinc in Soils and Crop Nutrition. Brussels: International Zinc Association Brussels.

Ancrenaz, M., Gumal, M., Marshall, A. J., Meijaard, E., Wich, S. A., and Husson, S. (2016). Pongo Pygmaeus. Gland: The IUCN Red List of Threatened Species.

Anderson, D. M., Fredrickson, E. L., and Estell, R. E. (2012). Managing livestock using animal behavior: mixed-species stocking and flerds. Animal 6, 1339-1349. doi: 10.1017/S175173111200016X

Andrès, E., Loukili, N. H., Noel, E., Kaltenbach, G., Abdelgheni, M. B., Perrin, A. E., et al. (2004). Vitamin B12 (cobalamin) deficiency in elderly patients. CMAJ. 171, 251-259. doi: 10.1503/cmaj.1031155

Asem-Hiablie, S., Battagliese, T., Stackhouse-Lawson, K. R., and Alan Rotz, C. (2019). A life cycle assessment of the environmental impacts of a beef system in the USA. Int. J. Life Cycle Assessment 24, 441-455. doi: 10.1007/s11367-018-1464-6

Atwood, S. B., Provenza, F. D., Wiedmeier, R. D., and Banner, R. E. (2001). Influence of free-choice vs mixed-ration diets on food intake and performance of fattening calves. J. Anim. Sci. 79, 3034-3040. doi: 10.2527/2001.79123034x

Avgerinos, K. I., Spyrou, N., Bougioukas, K. I., and Kapogiannis, D. (2018). Effects of creatine supplementation on cognitive function of healthy individuals: a systematic review of randomized controlled trials. Exp. Gerontol. 108, 166-173. doi: 10.1016/j.exger.2018.04.013

Bajaj, P. R., Tang, J., and Sablani, S. S. (2015). Pea protein isolates: Novel wall materials for microencapsulating flaxseed oil. Food Bioprocess Technol. 8, 2418-2428 doi: 10.1007/s11947-015-1589-6

Barabási, A.-L., Menichetti, G., and Loscalzo, J. (2019). The unmapped chemical complexity of our diet. Nature Food 1, 33-37. doi: 10.1038/s43016-019-0005-1

Barcelo-Coblijn, G., and Murphy, E. J. (2009). Alpha-linolenic acid and its conversion to longer chain $\mathrm{n}-3$ fatty acids: benefits for human health and a role in maintaining tissue n-3 fatty acid levels. Prog. Lipid Res. 48, 355-374. doi: 10.1016/j.plipres.2009.07.002

Bauch, A., Lindtner, O., Mensink, G. B. M., and Niemann, B. (2006). Dietary intake and sources of long-chain n-3 PUFAs in German adults. Eur. J. Clin. Nutr. 60, 810-812. doi: 10.1038/sj.ejcn.1602399

Bauer, J., Biolo, G., Cederholm, T., Cesari, M., Cruz-Jentoft, A. J., Morley, J. E., et al. (2013). Evidence-based recommendations for optimal dietary protein intake in older people: a position paper from the PROT-AGE Study Group. J. Am. Med. Dir. Assoc. 14, 542-559. doi: 10.1016/j.jamda.2013.05.021

Beck, K. L., Conlon, C. A., Kruger, R., and Coad, J. (2014). Dietary determinants of and possible solutions to iron deficiency for young women living in industrialized countries: a review. Nutrients 6, 3747-3776. doi: 10.3390/nu6093747

Bell, L. W., Moore, A. D., and Kirkegaard, J. A. (2014). Evolution in crop-livestock integration systems that improve farm productivity and environmental performance in Australia. Eur. J. Agronomy 57, 10-20. doi: 10.1016/j.eja.2013.04.007

Bemelmans, W. J., Lefrandt, J. D., Feskens, E. J., Van Haelst, P. L., Broer, J., Meyboom-De Jong, B., et al. (2004). Increased alpha-linolenic acid intake lowers C-reactive protein, but has no effect on markers of atherosclerosis. Eur. J. Clin. Nutr. 58, 1083-1089. doi: 10.1038/sj.ejcn.1601938
Benton, D., and Donohoe, R. (2011). The influence of creatine supplementation on the cognitive functioning of vegetarians and omnivores. Br. J. Nutr. 105, 1100-1105. doi: 10.1017/S0007114510004733

Bjelakovic, G., Nikolova, D., Gluud, L. L., Simonetti, R. G., and Gluud, C. (2012). Antioxidant supplements for prevention of mortality in healthy participants and patients with various diseases. Cochrane Database Syst Rev. 1-237. doi: 10.1002/14651858.CD007176.pub2

Bjorn-Rasmussen, E., and Hallberg, L. (1979). Effect of animal proteins on the absorption of food iron in man. Nutr. Metab. 23, 192-202. doi: $10.1159 / 000176256$

Bolland, M. J., Grey, A., Avenell, A., Gamble, G. D., and Reid, I. R. (2011). Calcium supplements with or without vitamin D and risk of cardiovascular events: reanalysis of the Women's Health Initiative limited access dataset and meta-analysis. BMJ 342:d2040. doi: 10.1136/bmj.d2040

Brenna, J. T. (2002). Efficiency of conversion of alpha-linolenic acid to long chain n-3 fatty acids in man. Curr. Opin. Clin. Nutr. Metab. Care 5, 127-132 doi: 10.1097/00075197-200203000-00002

Brennan, J. L., Keerati, U. R. M., Yin, H., Daoust, J., Nonnotte, E., Quinquis, L., et al. (2019). Differential responses of blood essential amino acid levels following ingestion of high-quality plant-based protein blends compared to whey protein-a double-blind randomized, cross-over, clinical trial. Nutrients 11:2987. doi: $10.3390 /$ nu11122987

Brenner, R. R. (1981). Nutritional and hormonal factors influencing desaturation of essential fatty acids. Prog. Lipid Res. 20, 41-47. doi: 10.1016/0163-7827(81)90012-6

Briskin, D. P. (2000). Medicinal plants and phytomedicines. Linking plant biochemistry and physiology to human health. J. Plant Physiol. 124, 507-514 doi: $10.1104 /$ pp.124.2.507

Burd, N. A., Groen, B. B., Beelen, M., Senden, J. M., Gijsen, A. P., and Van Loon, L. J. (2012). The reliability of using the single-biopsy approach to assess basal muscle protein synthesis rates in vivo in humans. Metabolism 61, 931-936. doi: 10.1016/j.metabol.2011.11.004

Burdge, G. C. (2006). Metabolism of alpha-linolenic acid in humans. Prostaglandins Leukot. Essent. Fatty Acids 75, 161-168. doi: 10.1016/j.plefa.2006.05.013

Burke, D. G., Chilibeck, P. D., Parise, G., Candow, D. G., Mahoney, D., and Tarnopolsky, M. (2003). Effect of creatine and weight training on muscle creatine and performance in vegetarians. Med. Sci. Sports Exerc. 35, 1946-1955. doi: 10.1249/01.MSS.0000093614.17517.79

Celaya, R., Benavides, R., García, U., Ferreira, L., Ferre, I., Martínez, A., et al. (2008). Grazing behaviour and performance of lactating suckler cows, ewes and goats on partially improved heathlands. Animal 2, 1818-1831. doi: $10.1017 /$ S1751731108003224

Chan, D. S., Lau, R., Aune, D., Vieira, R., Greenwood, D. C., Kampman, E., et al. (2011). Red and processed meat and colorectal cancer incidence: meta-analysis of prospective studies. PLoS ONE 6:e20456. doi: 10.1371/journal.pone.0020456

Chen, F., Du, M., Blumberg, J. B., Ho Chui, K. K., Ruan, M., Rogers, G., et al. (2019). Association among dietary supplement use, nutrient intake, and mortality among U.S. Adults: A Cohort Study. Ann. Intern. Med. 170, 604-613. doi: 10.7326/M18-2478

Conrad, M. E., and Umbreit, J. N. (1993). A concise review: iron absorptionthe mucin-mobilferrin-integrin pathway. A competitive pathway for metal absorption. Am. J. Hematol. 42, 67-73. doi: 10.1002/ajh.2830420114

Cooper, R., Naclerio, F., Allgrove, J., and Jimenez, A. (2012). Creatine supplementation with specific view to exercise/sports performance: an update. J. Int. Soc. Sports Nutr. 9:33. doi: 10.1186/1550-2783-9-33

Curtain, F., and Grafenauer, S. (2019). Plant-based meat substitutes in the flexitarian age: an audit of products on supermarket shelves. Nutrients 11:2603. doi: $10.3390 /$ nu11112603

Czerwonka, M., Szterk, A., and Waszkiewicz-Robak, B. (2014). Vitamin B12 content in raw and cooked beef. Meat Sci. 96, 1371-1375. doi: 10.1016/j.meatsci.2013.11.022

Dagnelie, P. C., Van Staveren, W. A., and Van Den Berg, H. (1991). Vitamin B12 from algae appears not to be bioavailable. Am. J. Clin. Nutr. 53, 695-697. doi: 10.1093/ajcn/53.3.695

Damayanti, D., Jaceldo-Siegl, K., Beeson, W. L., Fraser, G., Oda, K., and Haddad, E. H. (2018). Foods and supplements associated with vitamin B12 biomarkers 
among vegetarian and non-vegetarian participants of the adventist health study-2 (AHS-2) calibration Study. Nutrients 10:722. doi: 10.3390/nu10060722

Daniel, C. R., Cross, A. J., Koebnick, C., and Sinha, R. (2011). Trends in meat consumption in the USA. Public Health Nutr. 14, 575-583. doi: $10.1017 /$ S1368980010002077

Das, U. N. (2006). Essential fatty acids: biochemistry, physiology and pathology. Biotechnol. J. 1, 420-439. doi: 10.1002/biot.200600012

Dass, P., Houlton, B. Z., Wang, Y., and Warlind, D. (2018). Grasslands may be more reliable carbon sinks than forests in California. Environmental Research Letters 13:074027. doi: 10.1088/1748-9326/aacb39

Davey, G. K., Spencer, E. A., Appleby, P. N., Allen, N. E., Knox, K. H., and Key, T. J. (2003). EPIC-Oxford: lifestyle characteristics and nutrient intakes in a cohort of 33883 meat-eaters and 31546 non meat-eaters in the UK. Public Health Nutr. 6, 259-269. doi: 10.1079/PHN2002430

de Oliveira Otto, M. C., Alonso, A., Lee, D.-H., Delclos, G. L., Bertoni, A. G., Jiang, R., et al. (2012). Dietary intakes of zinc and heme iron from red meat, but not from other sources, are associated with greater risk of metabolic syndrome and cardiovascular disease. J. Nutr. 142, 526-533. doi: 10.3945/jn.111.149781

Deoula, S. M., El Kinany, K., Huybrechts, I., Gunter, M. J., Hatime, Z., Boudouaya, H. A., et al. (2019). Consumption of meat, traditional and modern processed meat and colorectal cancer risk among the Moroccan population: a large-scale case-control study. Int. J. Cancer 146:1333-1345. doi: 10.1002/ijc.32689

Derbyshire, E. (2018). Brain health across the lifespan: a systematic review on the role of omega-3 fatty acid supplements. Nutrients 10:1094. doi: $10.3390 /$ nu10081094

Deutz, N. E., Bauer, J. M., Barazzoni, R., Biolo, G., Boirie, Y., Bosy-Westphal, A., et al. (2014). Protein intake and exercise for optimal muscle function with aging: recommendations from the ESPEN Expert Group. Clin. 33, 929-936. doi: 10.1016/j.clnu.2014.04.007

Dominguez-Rodrigo, M., Pickering, T. R., Diez-Martin, F., Mabulla, A., Musiba, C., Trancho, G., et al. (2012). Earliest porotic hyperostosis on a 1.5million-year-old hominin, olduvai gorge, Tanzania. PLoS ONE 7:e46414. doi: 10.1371/journal.pone.0046414

Drewnowski, A., Rehm, C. D., Martin, A., Verger, E. O., Voinnesson, M., and Imbert, P. (2015). Energy and nutrient density of foods in relation to their carbon footprint. Am. J. Clin. Nutr. 101, 184-191. doi: 10.3945/ajcn.114.092486

Druesne-Pecollo, N., Latino-Martel, P., Norat, T., Barrandon, E., Bertrais, S., Galan, P., et al. (2010). Beta-carotene supplementation and cancer risk: a systematic review and metaanalysis of randomized controlled trials. Int. J. Cancer 127, 172-184. doi: 10.1002/ijc.25008

Eaton, S. B., Eaton, S. B. 3rd, Sinclair, A. J., Cordain, L., and Mann, N. J. (1998). Dietary intake of long-chain polyunsaturated fatty acids during the paleolithic. World Rev. Nutr. Diet 83, 12-23. doi: 10.1159/000059672

EFSA (2012). EFSA Panel on Dietetic Products, Nutrition, and Allergies. Scientific Opinion on the Tolerable Upper Intake Level of eicosapentaenoic acid (EPA), docosahexaenoic acid (DHA) and docosapentaenoic acid (DPA). EFSA J. 10:2815. doi: 10.2903/j.efsa.2012.2815

Enser, M., Hallett, K. G., Hewett, B., Fursey, G. A., Wood, J. D., and Harrington, G. (1998). The polyunsaturated fatty acid composition of beef and lamb liver. Meat Sci. 49, 321-327. doi: 10.1016/S0309-1740(97)00143-5

Eshel, G., Stainier, P., Shepon, A., and Swaminathan, A. (2019). Environmentally optimal, nutritionally sound, protein and energy conserving plant based alternatives to U.S. Meat. Sci. Reports 9:10345. doi: 10.1038/s41598-019-50289-8

Etcheverry, P., Hawthorne, K. M., Liang, L. K., Abrams, S. A., and Griffin, I. J. (2006). Effect of beef and soy proteins on the absorption of nonheme iron and inorganic zinc in children. J. Am. Coll. Nutr. 25, 34-40. doi: 10.1080/07315724.2006.10719512

Fang, X., An, P., Wang, H., Wang, X., Shen, X., Li, X., et al. (2015). Dietary intake of heme iron and risk of cardiovascular disease: a dose-response metaanalysis of prospective cohort studies. Nutr. Metab. Cardiovasc. Dis. 25, 24-35. doi: 10.1016/j.numecd.2014.09.002

FAO (2020). FAOSTAT Land Use module. Food and Agriculture Organization. Available online at: http://www.fao.org/faostat/en/\#data/RL/visualize (accessed January 6, 2020).

FAO/WHO/UNI (2011). Technical Report Series 935. Protein and Amino Acid Requirements in Human Nutrition: report of a joint fao/who/uni expert consultation.
Faunalytics (2015). Study of Current and Former Vegetarians and Vegans. Available online at: https://faunalytics.org/wp-content/ uploads/2015/07/Faunalytics-Study-of-Current-and-Former-Vegetarians-andVegans-Qualitative-Findings1.pdf (accessed November 14, 2019).

Ferreira, L. M. M., Celaya, R., Benavides, R., Jáuregui, B. M., García, U., Sofia Santos, A., et al. (2013). Foraging behaviour of domestic herbivore species grazing on heathlands associated with improved pasture areas. Livest. Sci. 155, 373-383. doi: 10.1016/j.livsci.2013.05.007

Fischer, B., and Lamey, A. (2018). Field deaths in plant agriculture. J. Agr. Environ. Ethics 31, 409-428. doi: 10.1007/s10806-018-9733-8

Foster, M., Chu, A., Petocz, P., and Samman, S. (2013). Effect of vegetarian diets on zinc status: a systematic review and meta-analysis of studies in humans. J. Sci. Food Agric. 93, 2362-2371. doi: 10.1002/jsfa.6179

Foster, M., and Samman, S. (2015). Vegetarian diets across the lifecycle: impact on zinc intake and status. Adv. Food Nutr. Res. 74, 93-131. doi: 10.1016/bs.afnr.2014.11.003

Fraser, R. Z., Shitut, M., Agrawal, P., Mendes, O., and Klapholz, S. (2018). Safety evaluation of soy leghemoglobin protein preparation derived from pichia pastoris, intended for use as a flavor catalyst in plant-based meat. Int. J. Toxicol. 37, 241-262. doi: 10.1177/1091581818766318

Froger, N., Moutsimilli, L., Cadetti, L., Jammoul, F., Wang, Q.-P., Fan, Y., et al. (2014). Taurine: the comeback of a neutraceutical in the prevention of retinal degenerations. Prog. Retin. Eye Res. 41, 44-63 doi: 10.1016/j.preteyeres.2014.03.001

Galan, P., Vergnaud, A.-C., Tzoulaki, I., Buyck, J.-F. O., Blacher, J., Czernichow, S. B., et al. (2009). Low total and nonheme iron intakes are associated with a greater risk of hypertension. J. Nutr. 140, 75-80. doi: 10.3945/jn.109.114082

Georgieff, M. K. (2007). Nutrition and the developing brain: nutrient priorities and measurement. Am. J. Clin. Nutrition 85, 614S-620S. doi: 10.1093/ajcn/85.2.614S

Gerber, P. J., Steinfeld, H., Henderson, B., Mottet, A., Opio, C., Dijkman, J., et al. (2013). Tackling Climate Change Through Livestock: A Global Assessment of Emissions and Mitigation Opportunities. Rome: Food and Agriculture Organization of the United Nations (FAO).

Gibson, R. S., Heath, A. L., and Szymlek-Gay, E. A. (2014). Is iron and zinc nutrition a concern for vegetarian infants and young children in industrialized countries? Am. J. Clin. Nutr. 100(Suppl. 1), 459s-468s. doi: 10.3945/ajcn.113.071241

Giraldo, M., Buodo, G., and Sarlo, M. (2019). Food processing and emotion regulation in vegetarians and omnivores: An event-related potential investigation. Appetite 141:104334. doi: 10.1016/j.appet.2019. 104334

Girard, C. L., and Matte, J. J. (2005). Effects of intramuscular injections of vitamin $\mathrm{B} 12$ on lactation performance of dairy cows fed dietary supplements of folic acid and rumen-protected methionine*. J. Dairy Sci. 88, 671-676. doi: 10.3168/jds.S0022-0302(05)72731-4

Glass, G. B., Skeggs, H. R., Lee, D. K., Jones, E. L., and Hardy, W. W. (1961). Hydroxocobalamin. I. Blood levels and urinary excretion of vitamin B12 in man after a single parenteral dose of aqueous hydroxocobalamin, aqueous cyanocobalamin and cyanocobalamin zinc-tannate complex. Blood 18, 511-521. doi: 10.1182/blood.V18.5.511.511

Godde, C. M., De Boer, I. J. M., Ermgassen, E. Z., Herrero, M., Van Middelaar, C. E., Muller, A., et al. (2020). Soil carbon sequestration in grazing systems: managing expectations. Clim. Change 161, 385-391. doi: 10.1007/s10584-020-02673-x

Godfray, H. C. J. (2019). Meat: The future series - alternative proteins. Geneva: World Economic Forum. Available online at: http://www3.weforum.org/docs/ WEF_White_Paper_Alternative_Proteins.pdf (accessed July 24, 2020).

Godfray, H. C. J., Aveyard, P., Garnett, T., Hall, J. W., Key, T. J., Lorimer, J., et al. (2018). Meat consumption, health, and the environment. Science 361:eaam5324. doi: 10.1126/science.aam5324

Goldberg, J., Flowerdew, G., Smith, E., Brody, J. A., and Tso, M. O. (1988). Factors associated with age-related macular degeneration. An analysis of data from the first National Health and Nutrition Examination Survey. Am. J. Epidemiol. 128, 700-707. doi: 10.1093/oxfordjournals.aje.a 115023

Goldstein, S., and Duca, A. (1982). Contributions to the analytical chemistry of vitamin B12. The thermal stability of cyanocobalamin, hydroxocobalamin and cobinamide in the solid state. Thermochimica Acta 59, 211-220 doi: $10.1016 / 0040-6031(82) 87129-3$ 
González, A. D., Frostell, B., and Carlsson-Kanyama, A. (2011). Protein efficiency per unit energy and per unit greenhouse gas emissions: potential contribution of diet choices to climate change mitigation. Food Policy 36, 562-570. doi: 10.1016/j.foodpol.2011.07.003

Gorelik, S., Ligumsky, M., Kohen, R., and Kanner, J. (2008). The stomach as a "bioreactor": when red meat meets red wine. J. Agric. Food Chem. 56, 5002-5007. doi: 10.1021/jf703700d

Gorissen, S. H., Horstman, A. M., Franssen, R., Crombag, J. J., Langer, H., Bierau, J., et al. (2016). Ingestion of wheat protein increases in vivo muscle protein synthesis rates in healthy older men in a randomized trial. J. Nutr. 146, 1651-1659. doi: 10.3945/jn.116.231340

Graça, J., Godinho, C. A., and Truninger, M. (2019). Reducing meat consumption and following plant-based diets: Current evidence and future directions to inform integrated transitions. Trends Food Sci. Technol. 91, 380-390. doi: 10.1016/j.tifs.2019.07.046

Haider, L. M., Schwingshackl, L., Hoffmann, G., and Ekmekcioglu, C. (2018). The effect of vegetarian diets on iron status in adults: a systematic review and meta-analysis. Crit. Rev. Food Sci. Nutr. 58, 1359-1374. doi: 10.1080/10408398.2016.1259210

Halpern, B. S., Cottrell, R. S., Blanchard, J. L., Bouwman, L., Froehlich, H. E., Gephart, J. A., et al. (2019). Opinion: Putting all foods on the same table: Achieving sustainable food systems requires full accounting. Proc. Natl. Acad. Sci. U.S.A. 116, 18152-18156. doi: 10.1073/pnas.1913308116

Harland, B. F., and Oberleas, D. (1987). Phytate in foods. World Rev. Nutr. Diet 52, 235-259. doi: 10.1159/000415199

Hartman, J. W., Tang, J. E., Wilkinson, S. B., Tarnopolsky, M. A., Lawrence, R. L., Fullerton, A. V., et al. (2007). Consumption of fat-free fluid milk after resistance exercise promotes greater lean mass accretion than does consumption of soy or carbohydrate in young, novice, male weightlifters. Am. J. Clin. Nutr. 86, 373-381 doi: 10.1093/ajcn/86.2.373

Hawken, P. (2017). Drawdown: The Most Comprehensive Plan Ever Proposed to Reverse Global Warming. New York, NY: Penguin Books.

Hayek, M. N., and Garrett, R. D. (2018). Nationwide shift to grass-fed beef requires larger cattle population. Environ. Res. Letters 13:084005. doi: $10.1088 / 1748-9326 / \mathrm{aad} 401$

Heller, M., and Keoleian, G. (2018). "Beyond Meat's Beyond Burger Life Cycle Assessment: A Detailed Comparison Between a Plant-Based and An AnimalBased Protein Source. Center for Sustainable Systems, University of Michigan. Available online at: http://css.umich.edu/project/comprehensive-comparisonplant-based-and-animal-based-protien-sources-beyond-meats-beyond (accessed November 12, 2019).

Herrmann, W., Obeid, R., Schorr, H., and Geisel, J. (2003a). Functional vitamin B12 deficiency and determination of holotranscobalamin in populations at risk. Clin. Chem. Lab. Med. 41, 1478-1488. doi: 10.1515/CCLM.2003.227

Herrmann, W., Schorr, H., Obeid, R., and Geisel, J. (2003b). Vitamin B-12 status, particularly holotranscobalamin II and methylmalonic acid concentrations, and hyperhomocysteinemia in vegetarians. Am. J. Clin. Nutr. 78, 131-136. doi: $10.1093 / \mathrm{ajcn} / 78.1 .131$

Hertz, H., Kristensen, H. P. Ø., and Hoff-Jørgensen, E. (1964). Studies on vitamin B12 retention comparison of retention following intramuscular injection of cyanocobalamin and hydroxocobalamin. Scand. J. Haematol. 1, 5-15. doi: 10.1111/j.1600-0609.1964.tb00001.x

Hodgkinson, S. M., Montoya, C. A., Scholten, P. T., Rutherfurd, S. M., and Moughan, P. J. (2018). Cooking conditions affect the true ileal digestible amino acid content and digestible indispensable amino acid score (DIAAS) of bovine meat as determined in pigs. J. Nutr. 148, 1564-1569. doi: 10.1093/jn/nxy153

Hou, Y., He, W., Hu, S., and Wu, G. (2019). Composition of polyamines and amino acids in plant-source foods for human consumption. Amino Acids 51, 1153-1165. doi: 10.1007/s00726-019-02751-0

Hunt, J. R., Gallagher, S. K., Johnson, L. K., and Lykken, G. I. (1995). High- versus low-meat diets: effects on zinc absorption, iron status, and calcium, copper, iron, magnesium, manganese, nitrogen, phosphorus, and zinc balance in postmenopausal women. Am. J. Clin. Nutr. 62, 621-632. doi: 10.1093/ajen/62.3.621

Hur, S. J., Lim, B. O., Park, G. B., and Joo, S. T. (2009). Effects of various fiber additions on lipid digestion during in vitro digestion of beef patties. J. Food Sci. 74, C653-C657. doi: 10.1111/j.1750-3841.2009.01344.x

Hurrell, R., and Egli, I. (2010). Iron bioavailability and dietary reference values. Am. J. Clin. Nutr. 91, 1461s-1467s. doi: 10.3945/ajcn.2010.28674F
Hurrell, R. F., Juillerat, M. A., Reddy, M. B., Lynch, S. R., Dassenko, S. A., and Cook, J. D. (1992). Soy protein, phytate, and iron absorption in humans. Am. J. Clin. Nutr. 56, 573-578. doi: 10.1093/ajcn/56.3.573

Institute of Medicine (2005). Dietary Reference Intakes for Energy, Carbohydrate, Fiber, Fat, Fatty Acids, Cholesterol, Protein, and Amino Acids. Washington, DC: The National Academies Press. doi: 10.17226/10490

International Food Information Council (2020). A Consumer Survey on Plant Alternatives to Animal Meat. Available online at: https://foodinsight.org/wpcontent/uploads/2020/01/IFIC-Plant-Alternative-to- Animal-Meat-Survey. pdf (accessed February 26, 2020).

IPCC (2019). Intergovernmental Panel on Climate Change. Climate Change and Land. Available online at: https://www.ipcc.ch/srccl/ (accessed January 6, 2020).

Jacobs, D. R. Jr., and Tapsell, L. C. (2007). Food, not nutrients, is the fundamental unit in nutrition. Nutr. Rev. 65, 439-450. doi: 10.1111/j.1753-4887.2007.tb00269.x

Jin, Y., He, X., Andoh-Kumi, K., Fraser, R. Z., Lu, M., and Goodman, R. E. (2018). Evaluating potential risks of food allergy and toxicity of soy leghemoglobin expressed in pichia pastoris. Mol. Nutr. Food Res. 62:1700297. doi: $10.1002 / \mathrm{mnfr} .201700297$

Kaluza, J., Larsson, S. C., Håkansson, N., and Wolk, A. (2014). Heme iron intake and acute myocardial infarction: a prospective study of men. Int. J. Cardiol. 172, 155-160. doi: 10.1016/j.ijcard.2013.12.176

Kanemoto, K., Moran, D., Shigetomi, Y., Reynolds, C., and Kondo, Y. (2019). Meat consumption does not explain differences in household food carbon footprints in Japan. One Earth 1, 464-471. doi: 10.1016/j.oneear.2019.12.004

Kappeler, R., Eichholzer, M., and Rohrmann, S. (2013). Meat consumption and diet quality and mortality in NHANES III. Eur. J. Clin. Nutr. 67, 598-606. doi: $10.1038 /$ ejen.2013.59

Karaca, A. C., Nickerson, M., and Low, N. H. (2013). Microcapsule production employing chickpea or lentil protein isolates and maltodextrin: physicochemical properties and oxidative protection of encapsulated flaxseed oil. Food Chem. 139, 448-457 doi: 10.1016/j.foodchem.2013.01.040

Kato, H., Suzuki, K., Bannai, M., and Moore, D. R. (2016). Protein requirements are elevated in endurance athletes after exercise as determined by the indicator amino acid oxidation method. PLOS ONE 11:e0157406. doi: 10.1371/journal.pone.0157406

Key, T. J., Appleby, P. N., Davey, G. K., Allen, N. E., Spencer, E. A., and Travis, R. C. (2003). Mortality in British vegetarians: review and preliminary results from EPIC-Oxford. Am. J. Clin. Nutr. 78, 533S-8S. doi: 10.1093/ajcn/78.3.533S

Khattab, R. Y., Arntfield, S. D., and Nyachoti, C. M. (2009). Nutritional quality of legume seeds as affected by some physical treatments, Part 1: protein quality evaluation. LWT-Food Sci. Technol. 42, 1107-1112. doi: 10.1016/j.lwt.2009.02.008

Kilb, W., and Fukuda, A. (2017). Taurine as an essential neuromodulator during perinatal cortical development. Front. Cell. Neurosci. 11:328. doi: $10.3389 /$ fncel.2017.00328

Kirmiz, N., Galindo, K., Cross, K. L., Luna, E., Rhoades, N., Podar, M., et al. (2020). CComparative genomics guides elucidation of vitamin B12 biosynthesis in novel human-associated Akkermansia strains. Appl. Environ. Microbiol. 86, e02117-e02119. doi: 10.1128/AEM.02117-19

Koh, L. P., and Wilcove, D. S. (2008). Is oil palm agriculture really destroying tropical biodiversity? Conserv. Lett. 1, 60-64. doi: 10.1111/j.1755-263X.2008.00011.x

Kristensen, M. B., Hels, O., Morberg, C., Marving, J., Bügel, S., and Tetens, I. (2005). Pork meat increases iron absorption from a 5-day fully controlled diet when compared to a vegetarian diet with similar vitamin $\mathrm{C}$ and phytic acid content. Br. J. Nutr. 94, 78-83. doi: 10.1079/BJN20051417

Kritchevsky, S. B. (1999). $\beta$-carotene, carotenoids and the prevention of coronary heart disease. J. Nutr. 129, 5-8. doi: 10.1093/jn/129.1.5

Kumar, B. M., and Nair, P. R. (2011). Carbon Sequestration Potential of Agroforestry Systems: Opportunities and Challenges. New York, NY: Springer Science \& Business Media.

Laidlaw, S. A., Grosvenor, M., and Kopple, J. D. (1990). The taurine content of common foodstuffs. J. Parenter. Enter. Nutr. 14, 183-188. doi: $10.1177 / 0148607190014002183$

Lee, J. E., Mclerran, D. F., Rolland, B., Chen, Y., Grant, E. J., Vedanthan, R., et al. (2013). Meat intake and cause-specific mortality: a pooled analysis of Asian prospective cohort studies. Am. J. Clin. Nutr. 98, 1032-1041. doi: 10.3945/ajcn.113.062638 
Li, K., Kaaks, R., Linseisen, J., and Rohrmann, S. (2012). Associations of dietary calcium intake and calcium supplementation with myocardial infarction and stroke risk and overall cardiovascular mortality in the Heidelberg cohort of the European prospective investigation into cancer and nutrition study (EPIC-Heidelberg). Heart 98, 920-925 doi: 10.1136/heartjnl-2011-301345

Li, Z., Henning, S. M., Zhang, Y., Zerlin, A., Li, L., Gao, K., et al. (2010). Antioxidant-rich spice added to hamburger meat during cooking results in reduced meat, plasma, and urine malondialdehyde concentrations. Am. J. Clin. Nutr. 91, 1180-1184. doi: 10.3945/ajcn.2009.28526

Liao, Y., Cooper, R. S., and Mcgee, D. L. (1994). Iron status and coronary heart disease: negative findings from the NHANES I epidemiologic follow-up study. Am. J. Epidemiol. 139, 704-712. doi: 10.1093/oxfordjournals.aje.a117060

Lichtenstein, A. H., and Russell, R. M. (2005). Essential nutrients: food or supplements?where should the emphasis be? JAMA 294, 351-358. doi: 10.1001/jama.294.3.351

Linnell, J. C., and Matthews, D. M. (1984). Cobalamin metabolism and its clinical aspects. Clin. Sci. 66, 113-121. doi: 10.1042/cs0660113

Lu, T., Shen, Y., Wang, J.-H., Xie, H.-K., Wang, Y.-F., Zhao, Q., et al. (2020). Improving oxidative stability of flaxseed oil with a mixture of antioxidants. $J$. Food Process. Pres. 44:e14355. doi: 10.1111/jfpp.14355

Lynch, J. (2019). Availability of disaggregated greenhouse gas emissions from beef cattle production: a systematic review. Environ. Impact Assess. Rev. 76, 69-78. doi: 10.1016/j.eiar.2019.02.003

Ma, Q., Kim, E. Y., and Han, O. (2010). Bioactive dietary polyphenols decrease heme iron absorption by decreasing basolateral iron release in human intestinal Caco-2 cells. J. Nutr. 140, 1117-1121. doi: 10.3945/jn.109.117499

Macdonald, J. C., Klopfenstein, T. J., Erickson, G. E., and Griffin, W. A. (2007). Effects of dried distillers grains and equivalent undegradable intake protein or ether extract on performance and forage intake of heifers grazing smooth bromegrass pastures. J. Anim. Sci. 85, 2614-2624. doi: 10.2527/jas.2006-560

Matte, J. J., Guay, F., and Girard, C. L. (2012). Bioavailability of vitamin B(1)(2) in cows' milk. Br. J. Nutr. 107, 61-66. doi: 10.1017/S0007114511002364

Maughan, M. W., Flores, J. P. C., Anghinoni, I., Bollero, G., Fernández, F. G., and Tracy, B. F. (2009). Soil quality and corn yield under crop-livestock integration in illinois. Agron. J. 101, 1503-1515. doi: 10.2134/agronj2009.0068

McAfee, A. J., Mcsorley, E. M., Cuskelly, G. J., Fearon, A. M., Moss, B. W., Beattie, J. A., et al. (2011). Red meat from animals offered a grass diet increases plasma and platelet n-3 PUFA in healthy consumers. Br. J. Nutr. 105, 80-89. doi: 10.1017/S0007114510003090

Mcclellan, W. S., and Du Bois, E. F. (1930). Clinical calorimetry XLV. Prolonged meat diets with a study of kidney function and ketosis. J. Biol. Chem. 87, 651-668.

Micha, R., Michas, G., and Mozaffarian, D. (2012). Unprocessed red and processed meats and risk of coronary artery disease and type 2 diabetes - an updated review of the evidence. Curr. Atheroscler. Rep. 14, 515-524. doi: 10.1007/s11883-012-0282-8

Miyazaki, T., Honda, A., Ikegami, T., and Matsuzaki, Y. (2013). “The role of taurine on skeletal muscle cell differentiation," in: Taurine 8, eds A. El Idrissi, and W. J. L'amoreaux (New York, NY: Springer), 321-328.

Morton, R. W., Murphy, K. T., Mckellar, S. R., Schoenfeld, B. J., Henselmans, M., Helms, E., et al. (2018). A systematic review, meta-analysis and meta-regression of the effect of protein supplementation on resistance training-induced gains in muscle mass and strength in healthy adults. Br. J. Sports Med. 52, 376-384. doi: 10.1136/bjsports-2017-097608

Mottet, A., De Haan, C., Falcucci, A., Tempio, G., Opio, C., and Gerber, P. (2017). Livestock: on our plates or eating at our table? A new analysis of the feed/food debate. Global Food Secur. 14, 1-8. doi: 10.1016/j.gfs.2017. 01.001

Nair, P. K. R., Tonucci, R. G., Garcia, R., and Nair, V. D. (2011). "Silvopasture and carbon sequestration with special reference to the Brazilian savanna (cerrado)," in Carbon Sequestration Potential of Agroforestry Systems: Opportunities and Challenges, eds. B. M. Kumar and P.K.R. Nair (Dordrecht: Springer Netherlands), 145-162.

Nwafor, I. C., Shale, K., and Achilonu, M. C. (2017). Chemical composition and nutritive benefits of chicory (Cichorium intybus) as an ideal complementary and/or alternative livestock feed supplement. Sci. World J. 2017:7343928. doi: $10.1155 / 2017 / 7343928$

Okuda, K., Yashima, K., Kitazaki, T., and Takara, I. (1973). Intestinal absorption and concurrent chemical changes of methylcobalamin. J. Lab. Clin. Med. $81,557-567$
Omenn, G. S., Goodman, G. E., Thornquist, M. D., Balmes, J., Cullen, M. R., Glass, A., et al. (1996). Effects of a combination of beta carotene and vitamin A on lung cancer and cardiovascular disease. N. Engl. J. Med. 334, 1150-1155. doi: 10.1056/NEJM199605023341802

Otsuka, R., Tange, C., Nishita, Y., Kato, Y., Imai, T., Ando, F., et al. (2014). Serum docosahexaenoic and eicosapentaenoic acid and risk of cognitive decline over 10 years among elderly Japanese. Eur. J. Clin. Nutr. 68, 503-509. doi: 10.1038/ejcn.2013.264

Pan, A., Sun, Q., Bernstein, A. M., Schulze, M. B., Manson, J. E., Willett, W. C., et al. (2011). Red meat consumption and risk of type 2 diabetes: 3 cohorts of US adults and an updated meta-analysis. Am. J. Clin. Nutr. 94, 1088-1096 doi: 10.3945/ajcn.111.018978

Papanikolaou, Y., Brooks, J., Reider, C., and Fulgoni, V. L. (2014). US adults are not meeting recommended levels for fish and omega-3 fatty acid intake: results of an analysis using observational data from NHANES 2003-2008. Nutr. J. 13:31. doi: 10.1186/1475-2891-13-31

Pasantes, H., Quesada, O., Alcocer, L., and Olea, R. (1989). Taurine content in foods. Nutr. Rep. Int. 40, 793-801.

Patel, K. V. (2008). Epidemiology of anemia in older adults. Semin. Hematol. 45, 210-217. doi: 10.1053/j.seminhematol.2008.06.006

Paul, C., and Brady, D. M. (2017). Comparative bioavailability and utilization of particular forms of $\mathrm{B}(12)$ supplements with potential to mitigate $\mathrm{B}(12)$-related genetic polymorphisms. Integr. Med. 16, 42-49.

Pawlosky, R. J., Hibbeln, J. R., Lin, Y., Goodson, S., Riggs, P., Sebring, N., et al. (2003). Effects of beef- and fish-based diets on the kinetics of n-3 fatty acid metabolism in human subjects. Am. J. Clin. Nutr. 77, 565-572. doi: 10.1093/ajcn/77.3.565

Payne, C. L. R., Scarborough, P., and Cobiac, L. (2016). Do low-carbonemission diets lead to higher nutritional quality and positive health outcomes? A systematic review of the literature. Public Health Nutr. 19, 2654-2661. doi: $10.1017 /$ S1368980016000495

Peters, C. J., Picardy, J., Wilkins, J. L., Griffin, T. S., Fick, G. W., and DarrouzetNardi, A. F. (2016). Carrying capacity of US agricultural land: ten diet scenarios. Elementa Sci. Anthrop. 4:1. doi: 10.12952/journal.elementa.000116

Phillips, S. M. (2012). Nutrient-rich meat proteins in offsetting age-related muscle loss. Meat Sci 92, 174-178. doi: 10.1016/j.meatsci.2012.04.027

Phillips, S. M., Chevalier, S., and Leidy, H. J. (2016). Protein “requirements" beyond the RDA: implications for optimizing health. Appl. Physiol. Nutr. Metab. 41, 565-572. doi: 10.1139/apnm-2015-0550

Piazza, J., Ruby, M. B., Loughnan, S., Luong, M., Kulik, J., Watkins, H. M., et al. (2015). Rationalizing meat consumption. The 4Ns. Appetite 91, 114-128. doi: 10.1016/j.appet.2015.04.011

Pierre, F., Taché, S., Petit, C. R., Van Der Meer, R., and Corpet, D. E. (2003). Meat and cancer: haemoglobin and haemin in a low-calcium diet promote colorectal carcinogenesis at the aberrant crypt stage in rats. Carcinogenesis 24, 1683-1690. doi: $10.1093 /$ carcin/bgg130

Pierrehumbert, R., and Eshel, G. (2015). Climate impact of beef: an analysis considering multiple time scales and production methods without use of global warming potentials. Environ. Res. Lett. 10:085002. doi: 10.1088/1748-9326/10/8/085002

Poore, J., and Nemecek, T. (2018). Reducing food's environmental impacts through producers and consumers. Science 360, 987-992 doi: 10.1126/science.aaq0216

Proulx, A. K., and Reddy, M. B. (2006). Iron bioavailability of hemoglobin from soy root nodules using a Caco-2 cell culture model. J. Agric. Food Chem. 54, 1518-1522. doi: 10.1021/jf0522681

Provenza, F. D., Villalba, J. J., Dziba, L., Atwood, S. B., and Banner, R. E. (2003). Linking herbivore experience, varied diets, and plant biochemical diversity. Small Rumin. Res. 49, 257-274. doi: 10.1016/S0921-4488(03)00143-3

Quantis International (2019a). Quantis International. Carbon Footprint Evaluation of Regenerative Grazing at White Oak Pastures. Prepared for general mills and white oak pastures. Available online at: https://blog.whiteoakpastures.com/ hubfs/WOP-LCA-Quantis-2019.pdf (accessed December 2, 2019).

Quantis International (2019b). "Quantis International. Comparative Environmental LCA of the Impossible Burger with Conventional Ground Beef Burger. Prepared for impossible foods. Available online at: https:// impossiblefoods.com/mission/lca-update-2019/ (accessed December 2, 2019).

Rallidis, L. S., Paschos, G., Liakos, G. K., Velissaridou, A. H., Anastasiadis, G., and Zampelas, A. (2003). Dietary alpha-linolenic acid decreases C-reactive protein, serum amyloid A and interleukin-6 in dyslipidaemic patients. Atherosclerosis 167, 237-242. doi: 10.1016/S0021-9150(02)00427-6 
Rapoport, S. I., Rao, J. S., and Igarashi, M. (2007). Brain metabolism of nutritionally essential polyunsaturated fatty acids depends on both the diet and the liver. Prostaglandins Leukot. Essent. Fatty Acids 77, 251-261. doi: 10.1016/j.plefa.2007.10.023

Reeder, J. D., and Schuman, G. E. (2002). Influence of livestock grazing on C sequestration in semi-arid mixed-grass and short-grass rangelands. Environ. Pollut. 116, 457-463. doi: 10.1016/S0269-7491(01)00223-8

Ridoutt, B., Anastasiou, K., Baird, D., Garcia, J. N., and Hendrie, G. (2020). Cropland footprints of Australian dietary choices. Nutrients 12:1212. doi: $10.3390 /$ nu12051212

Ripps, H., and Shen, W. (2012). Review: taurine: a "very essential" amino acid. Mol. Vis. 18, 2673-2686.

Rokicki, J., Li, L., Imabayashi, E., Kaneko, J., Hisatsune, T., and Matsuda, H. (2015). Daily carnosine and anserine supplementation alters verbal episodic memory and resting state network connectivity in healthy elderly adults. Front. Aging Neurosci. 7:219. doi: 10.3389/fnagi.2015.00219

Rosell, M. S., Lloyd-Wright, Z., Appleby, P. N., Sanders, T. A. B., Allen, N. E., et al. (2005). Long-chain $n-3$ polyunsaturated fatty acids in plasma in British meat-eating, vegetarian, and vegan men. Am. J. Clin. Nutr. 82, 327-334. doi: 10.1093/ajen/82.2.327

Rosenberg, K. V., Dokter, A. M., Blancher, P. J., Sauer, J. R., Smith, A. C., Smith, P. A., et al. (2019). Decline of the North American avifauna. Science 366:120-124. doi: $10.1126 /$ science.aaw1313

Rotz, C. A., Asem-Hiablie, S., Place, S., and Thoma, G. (2019). Environmental footprints of beef cattle production in the United States. Agric. Syst. 169, 1-13. doi: 10.1016/j.agsy.2018.11.005

Roussell, M. A., Hill, A. M., Gaugler, T. L., West, S. G., Ulbrecht, J. S., Vanden Heuvel, J. P., et al. (2014). Effects of a DASH-like diet containing lean beef on vascular health. J. Hum. Hypertens 28, 600-605. doi: 10.1038/jhh.2014.34

Rutherfurd, S. M., Fanning, A. C., Miller, B. J., and Moughan, P. J. (2014). Protein digestibility-corrected amino acid scores and digestible indispensable amino acid scores differentially describe protein quality in growing male rats. J. Nutr. 145, 372-379. doi: 10.3945/jn.114.195438

Sandström, B., Almgren, A., Kivistö, B., and Cederblad, Å. (1989). Effect of protein level and protein source on zinc absorption in humans. J. Nutr. 119, 48-53. doi: $10.1093 /$ in $/ 119.1 .48$

Sarwar Gilani, G., Wu Xiao, C., and Cockell, K. A. (2012). Impact of antinutritional factors in food proteins on the digestibility of protein and the bioavailability of amino acids and on protein quality. Br. J. Nutr. 108 (Suppl. 2), S315-S332. doi: $10.1017 /$ S0007114512002371

Savage, J. H., Kaeding, A. J., Matsui, E. C., and Wood, R. A. (2010). The natural history of soy allergy. J. Allergy Clin. Immunol. 125, 683-686. doi: 10.1016/j.jaci.2009.12.994

Schulze, M. B., Manson, J. E., Willett, W. C., and Hu, F. B. (2003). Processed meat intake and incidence of Type 2 diabetes in younger and middle-aged women. Diabetologia 46, 1465-1473. doi: 10.1007/s00125-003-1220-7

Scott, S. E., Inbar, Y., Wirz, C. D., Brossard, D., and Rozin, P. (2018). An overview of attitudes toward genetically engineered food. Annu. Rev. Nutr. 38, 459-479. doi: 10.1146/annurev-nutr-071715-051223

Seddon, J. M., Ajani, U. A., Sperduto, R. D., Hiller, R., Blair, N., Burton, T. C., et al. (1994). Dietary carotenoids, Vitamins A, C, and E, and advanced age-related macular degeneration. JAMA 272, 1413-1420. doi: 10.1001/jama.1994.03520180037032

Seetharam, B., and Alpers, D. H. (1982). Absorption and transport of cobalamin (vitamin B12). Аnnu. Rev. Nutr. 2, 343-369 doi: 10.1146/annurev.nu.02.070182.002015

Sheng, X., Wang, J., Li, F., Ouyang, F., and Ma, J. (2019). Effects of dietary intervention on vitamin $\mathrm{B}(12)$ status and cognitive level of 18-month-old toddlers in high-poverty areas: a cluster-randomized controlled trial. $B M C$ Pediatr. 19: 334. doi: 10.1186/s12887-019-1716-z

Simopoulos, A. P. (2002). The importance of the ratio of omega6/omega-3 essential fatty acids. Biomed. Pharmacother. 56, 365-379. doi: 10.1016/S0753-3322(02)00253-6

Sommer, A., and Vyas, K. S. (2012). A global clinical view on vitamin A and carotenoids. Am. J. Clin. Nutr. 96, 1204S-1206S. doi: 10.3945/ajcn.112.034868

Sprecher, H., Chen, Q., and Yin, F. Q. (1999). Regulation of the biosynthesis of 22:5n-6 and 22:6n-3: a complex intracellular process. Lipids 34, S153-S156. doi: 10.1007/BF02562271
Sruamsiri, S. (2007). Agricultural wastes as dairy feed in Chiang Mai. Anim. Sci. J. 78, 335-341. doi: 10.1111/j.1740-0929.2007.00445.x

Stanley, P. L., Rowntree, J. E., Beede, D. K., Delonge, M. S., and Hamm, M. W. (2018). Impacts of soil carbon sequestration on life cycle greenhouse gas emissions in Midwestern USA beef finishing systems. Agric. Syst. 162, 249-258. doi: 10.1016/j.agsy.2018.02.003

Stover, P. J., and Caudill, M. A. (2008). Genetic and epigenetic contributions to human nutrition and health: managing genome-diet interactions. J. Am. Diet. Assoc. 108, 1480-1487. doi: 10.1016/j.jada.2008.06.430

Stupperich, E., and Nexø, E. (1991). Effect of the cobalt-N coordination on the cobamide recognition by the human vitamin B12 binding proteins intrinsic factor, transcobalamin and haptocorrin. Eur. J. Biochem. 199, 299-303. doi: 10.1111/j.1432-1033.1991.tb16124.x

Su, H. M., Bernardo, L., Mirmiran, M., Ma, X. H., Nathanielsz, P. W., and Brenna, J. T. (1999). Dietary $18: 3 n-3$ and $22: 6 n-3$ as sources of 22:6n-3 accretion in neonatal baboon brain and associated organs. Lipids 34, S347S350. doi: 10.1007/BF02562339

Sunvold, G. D., Cochran, R. C., and Vanzant, E. S. (1991). Evaluation of wheat middlings as a supplement for beef cattle consuming dormant bluestem-range forage. J. Anim. Sci. 69, 3044-3054. doi: 10.2527/1991.6973044x

Suzuki, T., Suzuki, T., Wada, T., Saigo, K., and Watanabe, K. (2002). Taurine as a constituent of mitochondrial tRNAs: new insights into the functions of taurine and human mitochondrial diseases. EMBO J. 21, 6581-6589 doi: $10.1093 / \mathrm{emboj} / \mathrm{cdf} 656$

Swanson, D., Block, R., and Mousa, S. A. (2012). Omega-3 fatty acids EPA and DHA: health benefits throughout life. Adv. Nutr. 3, 1-7. doi: 10.3945/an.111.000893

Szczesniak, D., Budzen, S., Kopec, W., and Rymaszewska, J. (2014). Anserine and carnosine supplementation in the elderly: effects on cognitive functioning and physical capacity. Arch. Gerontol. Geriatr. 59, 485-490. doi: 10.1016/j.archger.2014.04.008

Tan, Z. S., Harris, W. S., Beiser, A. S., Au, R., Himali, J. J., Debette, S., et al. (2012). Red blood cell omega- 3 fatty acid levels and markers of accelerated brain aging. Neurology 78, 658-664. doi: 10.1212/WNL.0b013e318249f6a9

Tang, G. (2010). Bioconversion of dietary provitamin A carotenoids to vitamin A in humans. Am. J. Clin. Nutr. 91, 1468S-1473S. doi: 10.3945/ajcn.2010.28674G

Tang, J. E., Moore, D. R., Kujbida, G. W., Tarnopolsky, M. A., and Phillips, S. M. (2009). Ingestion of whey hydrolysate, casein, or soy protein isolate: effects on mixed muscle protein synthesis at rest and following resistance exercise in young men. J. Appl. Physiol. 107, 987-992. doi: 10.1152/japplphysiol.00076.2009

Teague, W., Apfelbaum, S., Lal, R., Kreuter, U., Rowntree, J., Davies, C., et al. (2016). The role of ruminants in reducing agriculture's carbon footprint in North America. J. Soil. Water Conser. 71, 156-164 doi: 10.2489/jswc.71.2.156

Tessari, P., Lante, A., and Mosca, G. (2016). Essential amino acids: master regulators of nutrition and environmental footprint? Sci. Rep. 6:26074. doi: $10.1038 /$ srep26074

The Alpha-Tocopherol Beta Carotene Cancer Prevention Study Group (1994). The effect of vitamin $\mathrm{E}$ and beta carotene on the incidence of lung cancer and other cancers in male smokers. N. Engl. J. Med. 330, 1029-1035. doi: 10.1056/nejm199404143301501

Tilman, D., and Clark, M. (2014). Global diets link environmental sustainability and human health. Nature 515:518-522. doi: 10.1038/nature 13959

Tucker, K. L., Olson, B., Bakun, P., Dallal, G. E., Selhub, J., and Rosenberg, I. H. (2004). Breakfast cereal fortified with folic acid, vitamin B-6, and vitamin B-12 increases vitamin concentrations and reduces homocysteine concentrations: a randomized trial. Am. J. Clin. Nutr. 79, 805-811. doi: 10.1093/ajen/79.5.805

Tucker, K. L., Rich, S., Rosenberg, I., Jacques, P., Dallal, G., Wilson, P. W., et al. (2000). Plasma vitamin B-12 concentrations relate to intake source in the framingham offspring study. Am. J. Clin. Nutr. 71, 514-522. doi: $10.1093 / \mathrm{ajcn} / 71.2 .514$

Umhau, J. C., Zhou, W., Carson, R. E., Rapoport, S. I., Polozova, A., Demar, J., et al. (2009). Imaging incorporation of circulating docosahexaenoic acid into the human brain using positron emission tomography. J. Lipid Res. 50, 1259-1268. doi: 10.1194/jlr.M800530-JLR200

USDA (2015). United States Department of Agriculture. By-Product Drop Value (STEER) - An Overview. Available online at: https://www.ams.usda.gov/ 
sites/default/files/media/ByProduct\%20DropValue\%28Steer\%29Overview.pdf (accessed June 6, 2020).

USDA (2016). USDA, Agricultural Research Service. National Nutrient Database for Standard Reference, Release 28. Washington, DC: USDA. Available online at: http://www.ars.usda.gov/ba/bhnrc/ndl (accessed November 14, 2019).

Van Hecke, T., Ho, P., Goethals, S., and De Smet, S. (2017a). The potential of herbs and spices to reduce lipid oxidation during heating and gastrointestinal digestion of a beef product. Food Res. Int. 102, 785-792 doi: 10.1016/j.foodres.2017.09.090

Van Hecke, T., Van Camp, J., and De Smet, S. (2017b). Oxidation during digestion of meat: interactions with the diet and helicobacter pylori gastritis, and implications on human health. Compr. Rev. Food Sci. Food Saf. 16, 214-233. doi: 10.1111/1541-4337.12248

van Poppel, G., and Goldbohm, R. A. (1995). Epidemiologic evidence for beta-carotene and cancer prevention. Am J Clin Nutr. 62, 1393s-1402s. doi: 10.1093/ajcn/62.6.1393S

van Vliet, S., Beals, J. W., Martinez, I. G., Skinner, S. K., and Burd, N. A. (2018). Achieving optimal post-exercise muscle protein remodeling in physically active adults through whole food consumption. Nutrients 10:224. doi: 10.3390/nu10020224

van Vliet, S., Burd, N. A., and Van Loon, L. J. (2015). The skeletal muscle anabolic response to plant- versus animal-based protein consumption. J. Nutr. 145, 1981-1991. doi: 10.3945/jn.114.204305

Van Zanten, H. H. E., Meerburg, B. G., Bikker, P., Herrero, M., and De Boer, I. J. M. (2016). Opinion paper: the role of livestock in a sustainable diet: a land-use perspective. Animal 10, 547-549. doi: 10.1017/S1751731115002694

Viglizzo, E. F., Ricard, M. F., Taboada, M. A., and Vázquez-Amábile, G. (2019). Reassessing the role of grazing lands in carbon-balance estimations: meta-analysis and review. Sci. Total Environ. 661, 531-542. doi: 10.1016/j.scitotenv.2019.01.130

Villalba, J. J., Beauchemin, K. A., Gregorini, P., and Macadam, J. W. (2019). Pasture chemoscapes and their ecological services. Transl. Anim. Sci. 3, 829-841. doi: $10.1093 /$ tas/txz003

Villalba, J. J., and Manteca, X. (2019). A case for eustress in grazing animals. Front. Vet. Sci. 6: 303. doi: 10.3389/fvets.2019.00303

Volek, J. S., Volk, B. M., Gomez, A. L., Kunces, L. J., Kupchak, B. R., Freidenreich, D. J., et al. (2013). Whey protein supplementation during resistance training augments lean body mass. J. Am. Coll. Nutr. 32, 122-135. doi: 10.1080/07315724.2013.793580

Vulcain, E., Goupy, P., Caris-Veyrat, C., and Dangles, O. (2005). Inhibition of the metmyoglobin-induced peroxidation of linoleic acid by dietary antioxidants: action in the aqueous vs. lipid phase. Free Radic. Res. 39, 547-563. doi: 10.1080/10715760500073865

Wadhwa, M., and Bakshi, M. (2013). Utilization of fruit and vegetable wastes as livestock feed and as substrates for generation of other value-added products. Rap Publication 4, 1-67.

Waldron, M., Patterson, S. D., Tallent, J., and Jeffries, O. (2018). The effects of oral taurine on resting blood pressure in humans: a meta-analysis. Curr. Hypertens. Rep. 20:81. doi: 10.1007/s11906-018-0881-z

Walker, J. W. (1994). Multispecies grazing: the ecological advantage. Sheep Goat Res. J. 1994:52-64. Unfortunately there is no DOI available for this publication.

Wang, Y., and Beydoun, M. A. (2009). Meat consumption is associated with obesity and central obesity among US adults. Int $J$ Obes. 33, 621-628. doi: $10.1038 /$ ijo.2009.45

Wang, Y.-Z., Fu, S.-G., Wang, S.-Y., Yang, D.-J., Wu, Y.-H. S., and Chen, Y.-C. (2018). Effects of a natural antioxidant, polyphenol-rich rosemary (Rosmarinus officinalis L.) extract, on lipid stability of plant-derived omega-3 fatty-acid rich oil. LWT 89, 210-216. doi: 10.1016/j.lwt.2017.10.055

Watanabe, F., and Bito, T. (2018). Vitamin B12 sources and microbial interaction. Exp. Biol. Med. 243, 148-158. doi: 10.1177/1535370217746612

Welch, R. M. (1993). "Zinc Concentrations and Forms in Plants for Humans and Animals," in Zinc in Soils and Plants: Proceedings of the International Symposium on 'Zinc in Soils and Plants' held at The University of Western Australia, ed. A. D. Robson (Dordrecht: Springer Netherlands), 183-195. doi: 10.1007/978-94-011-0878-2_13

WHO (2008). Interim Summary of Conclusions and Dietary Recommendations on Total Fat \& Fatty Acids From the Joint FAO/WHO Expert Consultation on Fats and Fatty Acids in Human Nutrition. Geneva: World Health Organization 10-14.
Wilkinson, S. B., Tarnopolsky, M. A., Macdonald, M. J., Macdonald, J. R., Armstrong, D., and Phillips, S. M. (2007). Consumption of fluid skim milk promotes greater muscle protein accretion after resistance exercise than does consumption of an isonitrogenous and isoenergetic soy-protein beverage. Am. J. Clin. Nutr. 85, 1031-1040. doi: 10.1093/ajcn/85.4.1031

Willett, W., Rockström, J., Loken, B., Springmann, M., Lang, T., Vermeulen, S., et al. (2019). Food in the anthropocene: the EAT-lancet commission on healthy diets from sustainable food systems. Lancet 393, 447-492. doi: 10.1016/S0140-6736(18)31788-4

Wolfe, R. R., and Miller, S. L. (2008). The recommended dietary allowance of protein: a misunderstood concept. JAMA 299, 2891-2893. doi: 10.1001/jama.299.24.2891

Wright, A. J., O'connor, L. E., Campbell, W. W., and Paddon-Jones, D. (2018). A Mediterranean-style eating pattern with lean, unprocessed red meat has cardiometabolic benefits for adults who are overweight or obese in a randomized, crossover, controlled feeding trial. Am. J. Clin. Nutr. 108, 33-40. doi: 10.1093/ajcn/nqy075

Xiao, Q., Murphy, R. A., Houston, D. K., Harris, T. B., Chow, W.-H., and Park, Y. (2013). Dietary and supplemental calcium intake and cardiovascular disease mortality: the national institutes of health-AARP diet and health study. JAMA Intern. Med. 173, 639-646. doi: 10.1001/jamainternmed.2013. 3283

Xue, L., Prass, N., Gollnow, S., Davis, J., Scherhaufer, S., Östergren, K., et al. (2019). Efficiency and carbon footprint of the german meat supply chain. Environ. Sci. Technol. 53, 5133-5142. doi: 10.1021/acs.est.8b06079

Yadrick, M. K., Kenney, M. A., and Winterfeldt, E. A. (1989). Iron, copper, and zinc status: response to supplementation with zinc or zinc and iron in adult females. Am. J. Clin. Nutr. 49, 145-150. doi: 10.1093/ajcn/49. 1.145

Yamada, K. (2013). "Cobalt: its role in health and disease," in Interrelations between Essential Metal Ions and Human Diseases, eds. A. Sigel, H. Sigel, and R. K. O. Sigel (Dordrecht: Springer Netherlands), 295-320.

Yang, Y., Churchward-Venne, T. A., Burd, N. A., Breen, L., Tarnopolsky, M. A., and Phillips, S. M. (2012). Myofibrillar protein synthesis following ingestion of soy protein isolate at rest and after resistance exercise in elderly men. Nutr. Metab. 9: 57. doi: 10.1186/1743-7075-9-57

Young, I., Parker, H. M., Rangan, A., Prvan, T., Cook, R. L., Donges, C. E., et al. (2018). Association between haem and non-haem iron intake and serum ferritin in healthy young women. Nutrients 10:81. doi: 10.3390/nu10010081

Yurko-Mauro, K., Alexander, D. D., and Van Elswyk, M. E. (2015). Docosahexaenoic acid and adult memory: a systematic review and meta-analysis. PLoS ONE 10:e0120391. doi: 10.1371/journal.pone. 0120391

Zheng, J. J., Mason, J. B., Rosenberg, I. H., and Wood, R. J. (1993). Measurement of zinc bioavailability from beef and a ready-to-eat high-fiber breakfast cereal in humans: application of a whole-gut lavage technique. Am J Clin Nutr. 58, 902-907. doi: 10.1093/ajcn/58.6.902

Zhuang, P., Wang, W., Wang, J., Zhang, Y., and Jiao, J. (2019). Polyunsaturated fatty acids intake, omega-6/omega-3 ratio and mortality: findings from two independent nationwide cohorts. Clin Nutr. 38, 848-855. doi: 10.1016/j.clnu.2018.02.019

Conflict of Interest: SV reports a grant from the North Dakota Beef Association to study the impact of diet quality on the relationship between red meat and human health and has not accepted personal honoraria from any organization to prevent undue influence in the eye of the public. FP reports receiving honoraria for his talks about behavior-based management of livestock.

The remaining author declares that the research was conducted in the absence of any commercial or financial relationships that could be construed as a potential conflict of interest.

Copyright (c) 2020 van Vliet, Kronberg and Provenza. This is an open-access article distributed under the terms of the Creative Commons Attribution License (CC BY). The use, distribution or reproduction in other forums is permitted, provided the original author(s) and the copyright owner(s) are credited and that the original publication in this journal is cited, in accordance with accepted academic practice. No use, distribution or reproduction is permitted which does not comply with these terms. 